\title{
The Silent Revolution in Europe: Intergenerational Change in Post-Industrial Societies*
}

\author{
RONALD INGLEHART \\ University of Michigan and University of Geneva
}

\section{Economic Scarcity and Political Priorities: An Analytic Framework}

A transformation may be taking place in the political cultures of advanced industrial societies. This transformation seems to be altering the basic value priorities of given generations, as a result of changing conditions influencing their basic socialization. The changes seem to affect the stand one takes on current political issues and may have a long-term tendency to alter existing patterns of political partisanship. In this article, I will present evidence based on surveys from six countries concerning these processes.

The findings seem to support a specific interpretation of the causes of value change in postindustrial societies; let me first outline this interpretation. My basic hypothesis is that given individuals pursue various goals in hierarchical order-giving maximum attention to the things they sense to be the most important unsatisfied needs at a given time. ${ }^{1} \mathrm{~A}$ man lost in a desert, for example, may be obsessed by his need for water, devoting virtually all his attention to the search for it. When a supply of water is readily available but food is scarce, he may take the former reed for granted (having achieved biological homeostasis in that respect) and may devote himself to gathering food. Once his food supply has reached a subsistence level, an individual may continue striving in order to pile up a comfortable margin of economic security; later, he may gradually shift his focus, coming to desire worldly goods as symbols of affluence - more in order to enhance his status among less affluent acquaintances than for the utility of the goods themselves. In a sense, however, the pursuit of symbols of affluence could be regarded as derivative from the search for sustenance.

* The author is indebted to Samuel Barnes, Karl Deutsch, Kent Jennings, Warren Miller, Robert Putnam, and Donald Stokes for comments and criticism of an earlier draft of this article.

1 For a more complete presentation of this hypothesis, see Ronald Inglehart, "Révolutionnarisme PostBourgeois en France, en Allemagne et aux Etats-Unis," Il Politico, 36, 2 (1971) 209-238; and Ronald Inglehart and Leon Lindberg, "Political Cleavages in Post-Industrial Society: the May Revolt in France" (forthcoming).
Important groups among the populations of Western societies have passed beyond these stages, we believe, and today are acting in pursuit of goals which (unlike symbols of affluence) no longer have a direct relationship to the imperatives of economic security. ${ }^{2}$ These individuals-drawn largely from the younger cohorts of the modern middle class-have been socialized during an unprecedentedly long period of unprecedentedly high affluence. For them, economic security may be taken for granted, as the supply of water or the air we breathe once could.

If this hypothesis is correct, it suggests that intergenerational political conflict is likely. We would expect to find such conflict if it is true that individuals have a tendency to retain a given value hierarchy throughout adult life, once a basic character has been formed during childhood and youth. An illustration would be the miser who experienced economic hardship during his childhood, saw hard work and frugality as a way out, and continued accumulating frantically long after his economic needs had been assured. This is, no doubt, an extreme case, but considerable evidence suggests that people do tend to retain early-instilled preferences. Drawing on the work of Abraham Maslow, ${ }^{3}$ we reason that the age cohorts who had experienced the wars and scarcities of the era preceding the West European economic miracles would accord a relatively high priority to economic security and to what Maslow terms the safety needs. For the younger cohorts, a set of "post-bourgeois" values, relating to the need for belonging and to asthetic and

\footnotetext{
2 An example of induced reversion to biological priorities, under starvation conditions, is described in James C. Davies, Human Nature and Politics (New York: Wiley, 1963), p. 13. A conscientious objector taking part in an experiment progressively lost his interest in social welfare work after a number of weeks on a semistarvation diet.

See Abraham H. Maslow, Motivation and Person. ality (New York: Harper, 1954). An excellent discussion of value hierarchies and their political implications appears in Robert E. Lane, Political Thinking and Consciousness (Chicago: Markham, 1970), Chapter 2.
} 
intellectual needs, would be more likely to take top priorities. ${ }^{4}$

Probably the best documented evidence of the persistence of early-instilled political preferences is found in the area of political party identification. ${ }^{5}$ But it is precisely in this area that our hypotheses have another interesting implication-they suggest the presence of a long-term pressure acting to reshape previous relationships between social class and political party preference. If the shift to a new set of value priorities results from attainment of a saturation level in regard to needs previously given top priority, we would expect a new ordering of values to manifest itself first and most fully among those groups that have attained the highest levels of affluence. In other words, we would expect to find it appearing first among the upper middle class, and among working class or farm groups only after a considerable delay. But despite the fact that middle-class status has generally tended to be associated with a preference for relatively conservative political parties, the newly emerging type of value priorities seems likely to be linked with support for radical social change. Under given conditions, we believe, this can lead to massive shifts to the political parties of the Left on the part of younger middle-class groups. Conversely, workingclass respondents would be relatively likely to have underlying value preferences which make them potential recruits for conservative parties - despite their traditional association with parties of the Left. These individuals have attained a certain level of prosperity relatively recently, and apparently continue to place a comparatively high value on defending and extending their recent gains. Paradoxically, although they have working-class occupations, they may manifest what is sometimes regarded as a "bourgeois" mentality.

\footnotetext{
4 Supporting evidence might be drawn from Richard Flacks' study of political activists and nonactivists among University of Chicago students. His findings indicate that students from relatively affluent homes tend to place greater emphasis on involvement in intellectual and esthetic pursuits, humanitarian considerations, and opportunities for self-expression, and they tend to de-emphasize material success, personal achievement, conventional morality, and religiosity; moreover, they are much more likely to become activists than students from less affiuent backgrounds. See Richard Flacks, "The Revolt of the Advantaged: An Exploration of the Roots of Student Protest," Journal of Social Issues, 23 (1967).

- See, among others, Angus Campbell, Philip Converse, Warren Miller and Donald Stokes, The American Voter (New York: Wiley, 1960). Cf. Philip Converse and Georges Dupeux, "Politicization of the Electorate in France and the U.S.," in Angus Campbell et al., Elections and the Political Order (New York: Wiley, 1966), Chapter 14.
}

In short, the "middle majority" hypothesis may have been correct, as far as it went: increasing affluence would make the working class feel they had a stake in the system. By comparison with the emerging post-bourgeois group, both the proletariat and bourgeoisie of industrial society shared certain acquisitive values; their conflicts were not due to differences in basic value priorities, but to the fact that one party had, and was overwhelmingly eager to keep, what the other party wanted above all. If this were, indeed, the case, an increasing degree of property ownership might well "embourgeoisify" the workers, lessening the intensity of class conflict. Nevertheless, Western societies do not seem to have reached a new era of consensual politics: the emergence of "post-bourgeois" value priorities among a small but critical sector of these societies may lead to a phase during which political cleavages will no longer be based primarily on the familiar economic conflicts - but will, increasingly, be polarized according to differences in underlying value priorities. $^{7}$ This new axis of political cleavage would, initially, oppose one section of the middle class to the remainder of society. Assuming continued prosperity, however, our analysis suggests that this deviant group would grow in relative size.

In a recent article, $s$ the outcome of the French 1968 uprising and elections was interpreted on the basis of the foregoing conceptual scheme. The May Revolt, we argued, was an event which had an exceptionally powerful impact on the French electorate, causing many voters to re-examine their habitual party preferences in the light of underlying values-and to realign themselves accordingly. Although the prevailing rhetoric of the May Revolt cast it as the movement of an exploited proletariat rising against bourgeois Gaullist oppression, in the subsequent elections the French working class showed a net shift which favored the Gaullists -while the modern middle class ${ }^{2}$ (especially

\footnotetext{
- This line of reasoning is presented in Ralf Dahrendorf, "Recent Changes in the Class Structure of European Societies"; and in Seymour Lipset, "The Chang. ing Class Structure and Contemporary European Politics," both in $A$ New Europe, ed., Stephen Graubard (Boston: Beacon, 1967).

Joseph Schumpeter reasoned along somewhat similar lines in Capitalism, Socialism and Democracy (New York: Harper, 1942).

${ }^{8}$ See Inglehart, op. cit.

- We distinguish between the modern middle class and the traditional middle class on the basis of occupation: the latter group consists of self-employed small businessmen and artisans; the former group comprises people with nonmanual occupations in the modern sector of the economy, and tends to be characterized by a higher level of economic security (and a lower
} 
its younger members) showed a net shift to the Left, by comparison with the way these groups had voted in 1967 . They apparently did so, in part, because the younger middle class tended to place a lower value on economic security and domestic order than did the workers. The disorders of 1968-particularly insofar as they entailed destruction of property-seem to have had a negative impact on the working class, driving many of them from their traditionally Leftist political loyalties toward support of General De Gaulle-who was widely seen as the guarantor of order.

Thanks to an ongoing program of public opinion research sponsored by the European Community, it was possible to take a set of predictions based on this interpretation of the 1968 French data and subject them to a more exhaustive cross-national test. Working in collaboration with the European Community Information Service, I took part in the design of a six-nation survey of political change in Western Europe, which went into the field in $1970 .^{10}$ Items included in these surveys were designed to tap politically relevant aspects of an individual's basic value hierarchy. We wanted to know which values a respondent would rank highest when he was forced to choose on the one hand between such things as economic security and domestic order (which we regarded as indicating instrumental or "acquisitive" values), and on the other items relating to expressive, or "post-bourgeois" value priorities. Our expectation was that those who had been socialized under conditions of relatively high and stable affluence should show a relative preference for such values as free speech and political participation. In the current social context, it was hypothesized, these values should be linked with a relatively change-oriented stand on current political issues. And if, as hypothesized, we are dealing with a basic, rather than a peripheral, aspect of the individual's socialization, we should find indications that these preferences influence a broad range of his political opinions.

We might expect the emergence of value preferences which do not conform to those of society as a whole to be linked with a prefer-

likelihood of being attracted to extreme-Right political movements). Our use of this distinction was suggested by Seymour Martin Lipset's analysis in Political Man: The Social Bases of Politics (Garden City: Doubleday, 1960), especially Chapter 5 .

${ }^{10}$ We are indebted to Jacques-René Rabier, directorgeneral of the European Community Information Service, for the role he has played in encouraging crossnational collaborative research with Michigan (and a number of other universities) over the past several years. ence for change-oriented political parties-in terms of traditional concepts, the parties of the Left. This tendency would be resisted, however, by another aspect of the presumed persistence of early political learning-the tendency toward persistence of early-instilled political party identification. To the extent that given individuals have acquired a sense of identification with the (traditionally middle-class) parties of the Right and Center, they would be slow to shift their support to a party of the Left, even assuming the presence of favorable underlying value preferences. The converse should also hold true; respondents who were raised in a Left-oriented political tradition would normally be somewhat inhibited from shifting to parties of the Right, even assuming the presence of relatively conservative value preferences.

\section{An Empirically-based Typology of Value Pri- orities and Its Expected Relationship to Economic History}

These hypotheses concern changes in value priorities over long periods of time. Very little relevant time-series data is available, and consequently one cannot test this interpretation directly. To do so conclusively would require a large-scale research program continuing over several decades. In the meantime, however, one can subject these hypotheses to a variety of indirect tests. While these tests cannot provide a definitive validation or falsification, they may aid the reader in forming a judgment concerning the relative plausibility of this interpretation, in the light of the total configuration of evidence.

The first type of indirect evidence is drawn from cross-sectional age-cohort analysis. This approach involves substantial methodological problems. Can one, in fact, draw conclusions about change over time from cross-sectional data? Under some conditions the answer, rather clearly, is yes: it depends on how much confidence one has that the cross-sectional data measure relatively stable characteristics of a given age cohort. ${ }^{11}$ To take an obvious example, you can project how many 21-year-olds there will be in the U.S. ten years from now

\footnotetext{
${ }^{11}$ For a sophisticated discussion and application of this type of analysis, see David Butler and Donald Stokes, Political Change in Britain: Forces Shaping Electoral Choice (New York: St. Martin's 1969), especially Chapters 3, 11 and 12. Butler and Stokes find that political party affiliation is a rather stable characteristic of British cohorts. In the relatively large swing from Conservative to Labour which took place from 1959 to 1963 , they conclude, replacement of the electorate (linked with differential birth and mortality rates) actually played a larger role than did conversion of voters from one party to the other.
} 
Table 1. Educational Level, by Age Cohort

(Percentage educated beyond primary school)

\begin{tabular}{lllllll}
\hline \hline $\begin{array}{c}\text { Age range of } \\
\text { cohort in } \\
1970\end{array}$ & Neth. & Belg. & Italy & France & Germany & Britain \\
\hline $16-24$ & $87 \%$ & 87 & 84 & 77 & 48 & 47 \\
$25-34$ & 66 & 69 & 60 & 62 & 39 & 37 \\
$35-44$ & 58 & 67 & 43 & 50 & 29 & 26 \\
$45-54$ & 44 & 50 & 35 & 39 & 33 & 24 \\
$55-64$ & 40 & 35 & 29 & 33 & 28 & 19 \\
$65+$ & 25 & 17 & 28 & 30 & 23 & 13 \\
\hline
\end{tabular}

and twenty years from now, if you have data on the size of the various age-groups today. Your prediction might be upset by a major war or other catastrophe, but otherwise it is likely to be fairly accurate. To take another example, let us look at the differences in educational levels among the respective age cohorts in our six national samples. (See Table 1.) The differences are quite sizeable, reflecting the massive expansion of secondary and higher education in Western Europe during the past two generations. These figures, I would argue, reflect a relatively enduring characteristic of the respective age cohorts: except among the youngest group, the level is unlikely to rise much; nor is it likely to decline for any of the cohorts. The presence of a high level of formal education may well have important effects on the political behavior of a given group. To the extent that such relationships can be demonstrated, longitudinal projections derived from the age-cohort differences are likely to be reasonably reliable.

With these remarks in mind, let us examine the pattern of responses to a series of items which were designed to measure an individual's hierarchy of politically relevant values. Representative national samples of the population over 15 years of age in Great Britain, Germany, Belgium, The Netherlands, France and Italy were asked the question: ${ }^{12}$

${ }^{13}$ Fieldwork was carried out in February and March, 1970, by Louis Harris Research, Ltd. (London), Institut für Demoskopie (Allensbach), International Research Associates (Brussels), Netherlands Institut voor de Publieke Opinie (Amsterdam), Institut français d'opinion publique (Paris), and Institut per le Ricerche Statische e l'Analisi del'opinione Pubblica (Milan). The respective samples had N's of: 1975 (Britain), 2021 (Germany), 1298 (Belgium), 1230 (Netherlands), 2046 (France), and 1822 (Italy).

The survey also included Luxembourg, but the number of respondents from that country (335) was considered too small for use in the present analysis. The Dutch sample has been weighed to correct for sampling deficiencies, and the weighted $N$ appears in the following tables; while the data from The Netherlands are, in the author's opinion, less reliable than those
"If you had to choose among the following things, which are the two that seem most desirable to you?

Maintaining order in the nation.

Giving the people more say in important political decisions.

Fighting rising prices.

Protecting freedom of speech."

Two choices only were permitted; thus (aside from nonresponse and partial nonresponse) it was possible for a respondent to select any of six possible pairs of items. In relation to my hypotheses, two of the items (the first and third) were regarded as indicating traditional "acquisitive" value preferences: a concern with domestic order is presumed to relate, above all, to the protection of property; ${ }^{13}$ and

from the other countries, the crucial intra-sample differences discussed in this article are sufficiently large as to minimize the likelihood that they simply reflect sampling error. On the other hand, cross-national comparisons based on the Dutch marginals should be viewed with reservations. The surveys in the European Community countries were sponsored by the European Community Information Service; research in Great Britain was supported by funds from the University of Michigan.

${ }^{13}$ From the viewpoint of most of our respondents, that is: in extreme situations, threats to domestic order can, of course, involve danger to one's life. To the extent that a concern with one's personal safety is involved, the item taps the need which Maslow places immediately below the economic needs in his hierarchy. Post-bourgeois responses, then, are seen as refiecting security in respect to both the economic and safeiy needs. There is reason to expect that the intergenerational pattern of priorities would be similar for the two types of needs: older cohorts are more likely to have experienced threats to their physical security, as well as to their economic security, during formative years. The persisting effect of the former experience is suggested by the fact that older Germans are more likely to express a fear of World War than are the post-war cohorts: see Peter Merkl, "Politico-Cultural Restraints on West-German Foreign Policy," Com:parative Political Studies, 3 (January, 1971). We doubt that many of our respondents felt physically threatened in 1970, however; for most, this item probably evokes nothing more than thoughts of property damage. 
Table 2. "Pure" Value Pairs, by Nation

(Percentage choosing each pair within given national sample)

\begin{tabular}{lcccccc}
\hline \hline Pair chosen: & Nether. & Belgium & Italy & France & Germany & Britain \\
\hline Acquisitive & $30 \%$ & 32 & 35 & 38 & 43 & 36 \\
Post-bourgeois & 17 & 14 & 13 & 11 & 10 & 8 \\
\hline
\end{tabular}

the relevance of rising prices to acquisitive motivations is fairly self-evident. The other two items in this set were regarded as indicating a preference for "post-bourgeois" values. I use the latter term with an awareness that political liberties were among the things traditionally valued by the bourgeoisie-but with the conviction that this group was characterized even more distinctively by a predominant concern for acquiring and retaining economic goods. It is not a question of valuing one thing positively and the other negatively: other items in our data indicate that most people place a positive value on all four of the above goals. But in politics it is sometimes impossible to maximize one good without detriment to another. In such cases, the relative priority among valued objectives becomes a vital consideration. Our questions, therefore, were cast in the form of forced-choice items in an attempt to measure these priorities. Empirically, it appears that although nearly everyone strongly favors freedom of speech (for example), there are striking differences in the priority given to it by various social groups.

The choice of one "post-bourgeois" item showed a relatively strong positive correlation with the choice of the other "post-bourgeois" item, in each national sample; the same was true of the two "acquisitive" items. Thus, approximately half of the respondents in each sample chose one of the two "pure" pairs of value preferences, with the other half spread over the four remaining "mixed" (or ambivalent) pairs, plus nonresponse. (See Table 2.) Note that the pure "acquisitive" pair predominates across the six samples by a ratio of at least $3: 1$.

On the basis of the choices made among these four items, it is possible to classify our

We follow the Marxist tradition in according an important role to economic determination-although only within certain thresholds. Both before industrialization and after an industrial society reaches a threshold of general economic security, we believe that other values are likely to prevail more widely. The concept of discretionary income is analogous to our interpretation of the second threshold: as an economy rises well above the subsistence level, even specifically economic behavior can be explained by economic variables to a progressively diminishing extent. respondents into value-priority groups, ranging from a "pure" acquisitive type to a "pure" postbourgeois type, with several intermediate categories. Use of this typology provides a simple, straightforward and intuitively meaningful basis for analysis. I should emphasize, however, that the use of these categories does not rest exclusively on an individual's choices among the four goals listed above. On the contrary, these four were selected as the basis of our typology because they seem to constitute a particularly sensitive indicator of a broad range of other political preferences - some of which have a fairly obvious relationship to the four basic items, and some of which appear to be quite distinct, in terms of face content. For example, on the basis of the value pair chosen by a given individual, one can make a fairly accurate prediction of his response to the following item:

"Within the last couple of years, there have been large-scale student demonstrations in (Britain) and other countries. In general, how do you view these? Are you:

-very favorable

-rather favorable

-rather unfavorable

-very unfavorable"

Table 3 shows the respective levels of support for student demonstrations in each of the six countries. While the majority is unfavorable in each country, there is a wide variation in support levels according to the pair of value choices made: a mean difference of fully fiftyfive percentage points separates the "acquisitive" and "post-bourgeois" types of respondents. In every country, respondents choosing the pure "post-bourgeois" pair are the group most favorable to student demonstrations, giving a heavy majority in support. Overall, they are more than four times as likely to favor the demonstrations as are the "acquisitive" respondents. With only one exception among the 36 value pairs shown, respondents choosing the pure "acquisitive" value pair are least favorable to the student demonstrations (in the one exceptional case, the "acquisitive" respondents are within three percentage points of the least favorable group).

Factor analyses of the respective national samples consistently showed these value choices 
Table 3. Attitude Toward Student Demonstrations, by Value Pairs Chosen

(Percentage favorable to student, demonstrations)

\begin{tabular}{lccccccc}
\hline \hline Nation & $\begin{array}{c}\text { Order } \\
\& \\
\text { Prices* }\end{array}$ & $\begin{array}{c}\text { Order \& } \\
\text { Free } \\
\text { Speech }\end{array}$ & $\begin{array}{c}\text { Order \& } \\
\text { Partici- } \\
\text { pation }\end{array}$ & $\begin{array}{c}\text { Prices \& } \\
\text { Free } \\
\text { Speech }\end{array}$ & $\begin{array}{c}\text { Prices \& } \\
\text { Partici- } \\
\text { pation }\end{array}$ & $\begin{array}{c}\text { Free Speech } \\
\text { \& Partici- } \\
\text { pation* }\end{array}$ & Overall \\
\hline Neth. & $21 \%$ & 33 & 42 & 37 & 47 & 70 & $39 \%$ \\
Italy & 19 & 29 & 36 & 42 & 54 & 77 & 36 \\
Belg. & 18 & 29 & 36 & 32 & 60 & 65 & 35 \\
Germ. & 14 & 35 & 29 & 35 & 46 & 83 & 32 \\
France & 12 & 18 & 23 & 38 & 41 & 66 & 27 \\
Brit. & 12 & 22 & 9 & 22 & 60 & 65 & 17 \\
mean: & $16 \%$ & 28 & 29 & 35 & 51 & 71 & \\
\hline
\end{tabular}

"Indicates the two "pure" value pairs, on the basis of our hypothesis-representing, respectively, "acquisitive" and "post-bourgeois" values.

to be among the high-loading items (in a set of 25 variables) on what I interpret as an "acquisitive/post-bourgeois values" factor. ${ }^{14}$ In every case, the choice of "order" and "prices" had relatively high negative loadings on this factor, while the choice of "free speech"" and "'participation" had relatively high positive loadings.

In view of the face content of the items, it is not particularly surprising that we find a strong relationship between these value choices and the respondents' support of or opposition to student demonstrations. But these same value choices also show significant relationships with other political preferences which have no obvious similarity in terms of face content. For example, they serve as good predictors of attitudes toward supranational European integration. Table 4 shows the relationship between value choices and responses to a three-item index of support for European integration. ${ }^{15}$

\footnotetext{
"Other high-loading items on this factor related to: expectations of a higher standard of living, support for student demonstrations, support for radical social change, and support for a variety of proposals for European integration (all of which had positive polarity); and emphasis on job security, pride in one's own nationality, and support for a strong national army (which bad negative polarity). Because of limited funds, the British questionnaire was shorter than the one used in the European Community countries, and the factor analysis for that sample omits some of the items available in the larger data sets. Apart from these omissions, the British response pattern seems to parallel that found on the Continent. The fact that expectations of a higher future standard of living seem to go with giving a relatively low priority to economic security is interesting: it tends to confirm our interpretation that, for the post-bourgeois group, economic values are relatively unimportant because they are taken for granted.

1s This index was based on responses to the following items: "Supposing the people of Britain and the Common Market were asked to decide on the following questions. How would you vote ...?
}

Once again, we find the two theoretically "pure" sets of value priorities occupying the opposite poles of the continuum-with postbourgeois respondents markedly more European in outlook than the acquisitive-type respondents. There are only two mild exceptions to the rule that the respondents choosing the theoretically "ambivalent" value pairs are more European than the theoretically pure acquisitives types, and less European than the postbourgeois types. The ordering within the "ambivalent" pairs changes somewhat from the pattern we found in Table 3, with a concern for rising prices now showing a stronger association with the negative end of the scale than the preoccupation with domestic order which formerly held that place; in other respects, the ranking of value pairs remains the same. Overall, the post-bourgeois respondents are more than twice as likely to be classified as "clearly

-Would you be in favor of, or against, the election of a European parliament by direct universal suffrage; that is, a parliament elected by all the voters in the member countries?

-Would you bo willing to accept, over and above the (British) government, a European government responsible for a common policy in foreign affairs, defense and the economy?

-If a President of a United States of Europe were being elected by popular vote, would you be willing to vote for a candidate not of your own country, if his personality and programme corresponded more closely to your ideas than those of the candidates from your own country?"

A respondent was categorized as "clearly for" European integration if he gave favorable responses to all three of these items; or to at least two of them provided that his response to the third item was "don't know," rather than "against." For a much more detailed exploration of this topic, see my article "Changing Value Priorities and European Integration," Journal of Common Market Studies, September, 1971. 
Table 4. Support for European Integration, by Value Pairs Chosen

(Percentage scored as "Clearly For" on European Integration Index)

\begin{tabular}{lccccccc}
\hline \hline Nation & $\begin{array}{c}\text { Prices } \\
\& \\
\text { Order* }\end{array}$ & $\begin{array}{c}\text { Prices \& } \\
\text { Free } \\
\text { Speech }\end{array}$ & $\begin{array}{c}\text { Prices \& } \\
\text { Partici- } \\
\text { pation }\end{array}$ & $\begin{array}{c}\text { Order \& } \\
\text { Free } \\
\text { Speech }\end{array}$ & $\begin{array}{c}\text { Order \& } \\
\text { Partici- } \\
\text { pation }\end{array}$ & $\begin{array}{c}\text { Free Speech } \\
\text { \& Partici- } \\
\text { pation* }\end{array}$ & Overall \\
Italy & $48 \%$ & 53 & 63 & 65 & 73 & 69 & $57 \%$ \\
Germany & 45 & 57 & 64 & 67 & 59 & 76 & 55 \\
France & 36 & 38 & 48 & 48 & 61 & 69 & 44 \\
Belgium & 31 & 39 & 43 & 46 & 50 & 64 & 42 \\
Netherlands & 28 & 31 & 34 & 43 & 52 & 62 & 39 \\
Britain & 13 & 16 & 16 & 36 & 20 & 32 & 17 \\
mean: & $30 \%$ & 36 & 41 & 47 & 49 & 61 & \\
\hline
\end{tabular}

*Indicates the two "pure" value pairs.

for" supranational European integration as are the acquisitive respondents. ${ }^{16}$

As we shall see presently, these value choices also show a rather striking set of relationships with social structure and political party preferences. This is scarcely the sort of pattern which would emerge from random answering or from a superficial response to transient stimuli. It appears that these items tap a relatively well integrated and deep-rooted aspect of the respondents' political orientations.

If these items do tap attitudes that are early established and relatively persistent, responses to them should show distinctive patterns, refiecting distinctive conditions which prevailed during the formative years of the respective age cohorts. Our next step, therefore, is to examine variations in response according to age group. Before doing so, let us attempt to specify, as precisely as possible, what sort of pattern we

\footnotetext{
${ }^{10}$ There is a certain similarity between the configuration of "post-bourgeois" preferences and the wellknown concept of "authoritarianism." Both concepts relate to the priorities one gives to liberty, as opposed to order. And-as we have just seen-the libertarian position seems linked with internationalism. This follows from the fact that, according to our analysis, the post-bourgeois groups have attained security in regard to both the safety and sustenance needs; insofar as the nation-state is seen as a bulwark protecting the individual against foreign threats, it is less important to post-bourgeois respondents. They have, moreover, a larger amount of "venture capital," psychically speaking, available to invest in projects having an intellectual and esthetic appeal-such as European unification. There are both theoretical and empirical differences between our position and that prevailing in the authoritarianism literature. We emphasize a process of historically-shaped causation which is not necessarily incompatible with, but certainly takes a different focus from, the psychodynamics of authoritarianism. Empirically, authoritarianism, like acquisitive value priorities, tends to be linked with lower economic status. By contrast, there are indications that children and youth tend to be more authoritarian than adults.
}

would expect to find on the basis of our analytic framework.

In the first place, the most recently formed cohorts should show the highest proportion of post-bourgeois responses and the lowest proportion of acquisitive responses, in every national sample. The respondents born after 1945 constitute the only group which (as far back as their memory reaches) has been socialized entirely under conditions of rising affluence, uninterrupted by major economic dislocations. As a first approximation, therefore, we would predict that: (1) the distribution of attitudes should resemble an L-shaped curve, with a very low proportion of post-bourgeois attitudes being found among respondents born before 1945 , and a sharp rise in the prevalence of post-bourgeois values among those born after that date; conversely, the occurrence of acquisitive values should be uniformly high among all

(Stouffer, however, reported evidence of sizeable agegroup differences among adult groups in degree of "Tolerance for Non-Conformity," with young adults far more tolerant than older adults; he sees the evidence as reflecting both life-cycle and intergenerational effects. See Samuel Stouffer, Communism, Conformity and Civil Liberties [New York: Doubleday, 1955], p. 89). In any event, neither previous explorations nor the present surveys revealed reasonably strong or consistent relationships between standardized F-scale items and the attitudes reported here. The two concepts seen related, but items which served as indicators of authoritarianism in earlier research appear to bave limited applicability in the Europe of the 1970's. For a report of an earlier cross-national exploration of authoritarianism and internationalism, see Ronald Inglehart, "The New Europeans: Inward or Outward Looking?" International Organization, Vol. 24, No. 1 (Winter, 1970), pp. 129-139. The literature on authoritarianism is immense; the classic work is Theodor W. Adomo, et al., The Authoritarian Personality (New York: Harper, 1950); Cf. Richard Christie and Marie Jahoda, eds., Studies in the Scope and Method of "The Authoritarian Personality" (Glencoe: Free Press, 1954). 


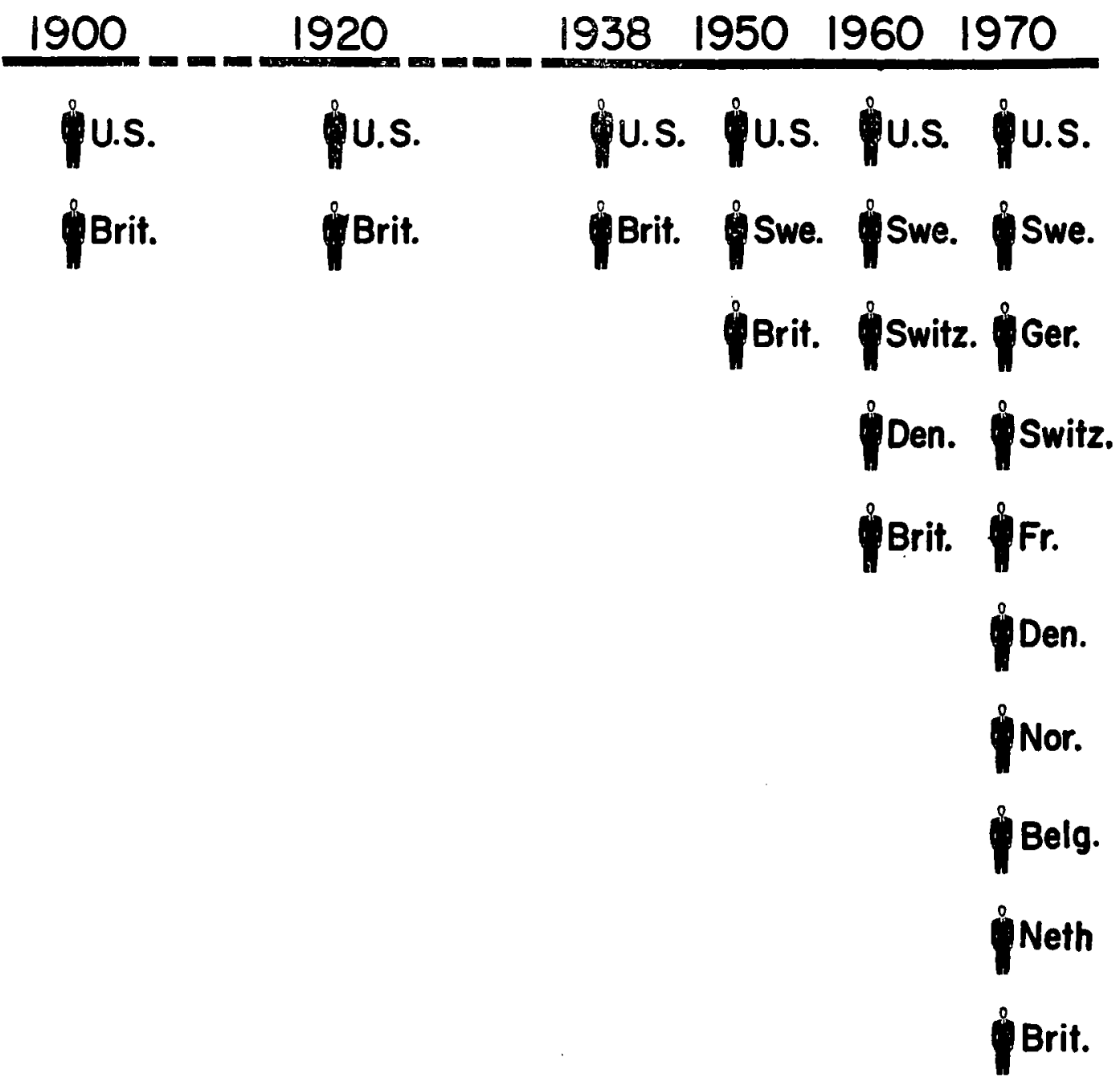

Figure 1. The decline in Britain's relative economic position. The U.S. and major European countries ranked according to per capita Gross National Product, 1900 to 1970. (Source: "The Economist," September 5, 1970, p. 69.)

cohorts born before 1945 , with a precipitate drop as we reach the postwar cohorts. This pattern can only serve as a first approximation of course. It would be ridiculous to argue that no change in basic values can occur during adult life; our point is simply that the probability of such change becomes much lower after one reaches adulthood, and probably continues to decline thereafter. To the extent that adult relearning takes place, it would tend to smooth out the basic L-shaped curve. The fact that value preferences probably crystallize in different individuals at somewhat different ages, would also tend to have this effect.

We would not expect to find a zero incidence of post-bourgeois values even among the oldest cohorts: there has always been at least a small stratum of economically secure individuals, able to give top priority to nonacquisitive values. But this stratum should be smallest among the oldest cohorts if, indeed, it tends to reflect the level of affluence prevailing within a given society during a given cohort's pre-adult years.

By the same token the distribution of these value preferences should vary cross-nationally in a predictable fashion-reflecting the economic history of the given nation. Fortunately for our analysis, there are substantial differences in the 20th-century economic experiences of the nations in our sample. These variations enable us to make predictions about the relative level and steepness of the value-distribution curves for given nations. To put it briefly, high absolute levels of wealth in a given nation at a given time would predict relatively high proportions of post-bourgeois respondents among 
the cohorts socialized under those conditions; high rates of growth for a given country would predict relatively large increases in the proportion of post-bourgeois respondents, across that nation's age-groups. The economic progress of Great Britain, in particular, shows a sharp contrast with that of the other five nations. Throughout the first four decades of the 20th century, Britain-the home of the first Industrial Revolution-was by far the wealthiest country in Europe, and in world wide comparisons it ranked second only to the U.S. (and, sometimes, Canada) in per capita income. During the decade before World War II, among the nations in our sample, The Netherlands ranked closest to Britain (with a per capita income 71 per cent as high as the British) followed by France, Belgium and Germany, with Italy far behind (having only 27 per cent the per capita income of Britain). In the postwar era, the economically privileged position which Britain had long enjoyed began to deteriorate rapidly (see Figure 1). Although her absolute level of income rose gradually (interrupted by periods of stagnation), Britain was overtaken by one after another of her European neighbors-nearly all of which experienced much more rapid and continuous economic growth; these growth rates were particularly steep in the case of Germany and Italy (see Figure 2). By 1970, Britain had been outstripped by five of the six European Community countries, with the sixth (Italy) not far behind.

On the basis of these historical data, we can make four predictions about the expected value-distribution curves in addition to the $\mathrm{L}$ shaped curve posited earlier in our first prediction. (2) Among those respondents who reached adulthood before World War II, the size of the stratum which had known economic security during its formative years would be small-but its relative size should be greater in the British sample than in the other national samples. Translated into expected survey results, this means that the British cohorts now in their mid-50's or older should show the highest frequency of post-bourgeois values. (3) The rate of value change found in Britain, however, should be much lower than that in the other five countries. Her economic growth rate since World War II has been approximately half that of the average among the European Community countries; as a first approximation, we might expect the rate of increase in post-bourgeois values found among Britain's younger cohorts to be half as great as that within the EEC. (4) In prevalence of post-bourgeois values among the younger cohorts, we might expect Britain to be outstripped by all of the European Commu-

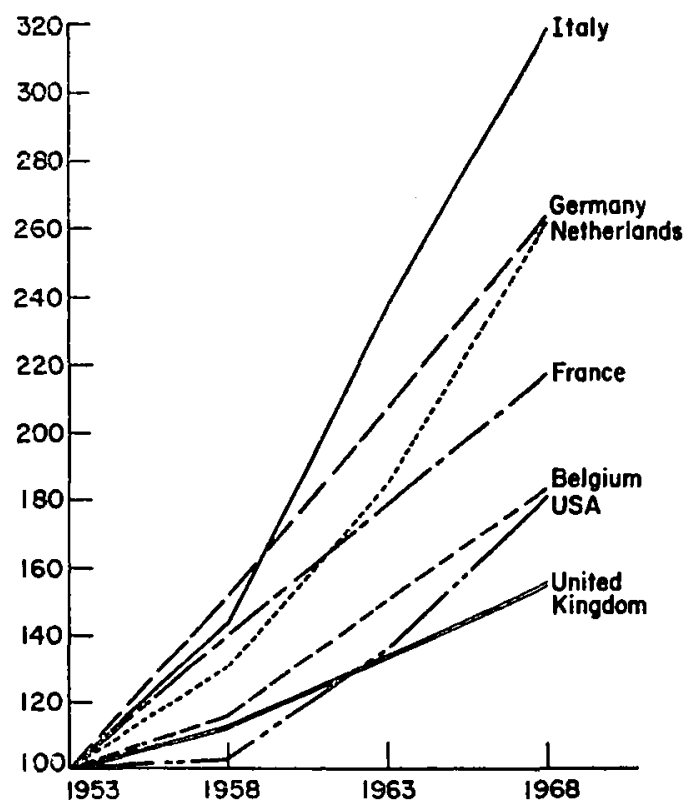

Figure 2. Economic growth, 1953-68. Based on indices of industrial production $(1953=1.00)$. Source: "U.N. Statistical Yearbook, 1969."

The year 1953 is taken as our base line to avoid giving undue prominence to recovery from the devastation of World War II: using 1948 or 1945 as a base would tend to exaggerate the disparity between Germany and Italy (on one hand) and Great Britain (on the other hand).

nity countries except Italy. (5) Among these six nations, Germany and Italy - the two countries experiencing the most rapid economic change during the post-war era--should show the greatest amount of intergenerational change in basic value priorities. ${ }^{17}$

With these five predictions in mind, let us examine the empirical relationship between value preferences and age cohort, within each national sample. (See Table 5.) Our basic prediction-that the younger cohorts will be less likely to show acquisitive value priorities and more likely to show post-bourgeois values-is confirmed strikingly. Among the oldest cohort, the disproportionate preference for the pure

${ }^{17}$ It is difficult to interpret the cross-national pattern as a reaction to current events within the respective nations. There is considerable evidence of a recent law-and-order reaction in the face of student disorders in each of these countries. But if the cross-national differences were largely the result of such a reaction, we would expect to find the emphasis on order to be greatest in France (where the recent upheaval was greatest) and weakest in Britain (which has had the smallest amount of domestic disorder). The data manifestly fail to fit this pattern; we must explain them in terms of predispositions anterior to, rather than resulting from, the recent domestic disorders these countries have experienced. 
Table 5. "Pure" Value Preferences, by Age Cohort

(Percentage choosing each pair)*

\begin{tabular}{|c|c|c|c|c|c|c|c|c|c|c|c|c|}
\hline \multirow{2}{*}{$\begin{array}{c}\text { Age Range } \\
\text { of cohort in } \\
1970\end{array}$} & \multicolumn{2}{|c|}{ Netherlands } & \multicolumn{2}{|r|}{ Belgium } & \multicolumn{2}{|r|}{ Italy } & \multicolumn{2}{|r|}{ France } & \multicolumn{2}{|c|}{ Germany } & \multicolumn{2}{|r|}{ Britain } \\
\hline & Aug. & P-B N & Acq. & $\mathbf{P}-\mathbf{B} \mathbf{N}$ & Acq. & $\mathbf{P}-\mathbf{B} \mathbf{N}$ & Acq. & P-B N & Acq. & $\mathbf{P}-\mathbf{B} \mathbf{N}$ & Acq. & P-B N \\
\hline \multirow{3}{*}{ 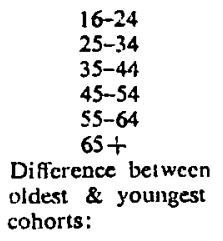 } & $\begin{array}{l}20 \% \\
27 \\
36 \\
29 \\
37 \\
44\end{array}$ & $\begin{array}{r}29(442) \\
16(408) \\
14(406) \\
15(285) \\
7(223) \\
5(138)\end{array}$ & $\begin{array}{l}19 \\
35 \\
28 \\
29 \\
37 \\
45\end{array}$ & $\begin{array}{r}26(227) \\
13(211) \\
19(234) \\
13(188) \\
8(201) \\
2(235)\end{array}$ & $\begin{array}{l}18 \\
30 \\
36 \\
37 \\
42 \\
54\end{array}$ & $\begin{array}{r}28(335) \\
15(256) \\
11(397) \\
8(310) \\
7(315) \\
4(193)\end{array}$ & $\begin{array}{l}21 \\
35 \\
36 \\
39 \\
48 \\
50\end{array}$ & $\begin{array}{r}20(365) \\
11(369) \\
14(347) \\
10(319) \\
6(280) \\
2(360)\end{array}$ & $\begin{array}{l}21 \\
35 \\
46 \\
47 \\
60 \\
56\end{array}$ & $\begin{array}{r}23(317) \\
15(409) \\
8(372) \\
7(326) \\
4(325) \\
2(265)\end{array}$ & $\begin{array}{l}25 \\
29 \\
29 \\
37 \\
41 \\
50\end{array}$ & $\begin{array}{r}14(254) \\
9(340) \\
8(278) \\
5(398) \\
8(331) \\
5(374)\end{array}$ \\
\hline & \multicolumn{2}{|c|}{48} & \multicolumn{2}{|c|}{50} & \multicolumn{2}{|c|}{60} & \multicolumn{2}{|c|}{47} & \multicolumn{2}{|c|}{56} & \multicolumn{2}{|c|}{34} \\
\hline & -24 & +24 & -26 & +24 & -36 & +24 & -29 & +18 & -35 & +21 & -25 & +9 \\
\hline
\end{tabular}

* Number in parentheses is base on which percentages are calculated.

"acquisitive" pair is overwhelming: half or nearly half of the entire cohort choose that one pair, out of six possibilities. Most of the remaining respondents in this cohort are ambivalent; a relative handful-in no case more than five per cent-chooses the post-bourgeois set of priorities. Overall, acquisitive types outnumber post-bourgeois types by a ratio of better than 15:1 in this cohort. As we move up the table from the oldest to the youngest cohort, the proportion choosing the pure "acquisitive" pair falls off markedly, diminishing by considerably more than one-half in every sample except the British; even in the latter case, the decline is just equal to 50 per cent. As we move from oldest to youngest, the increase in the proportion choosing the post-bourgeois priorities is proportionately even greater: even in the British sample, where the indications of change over time are weakest, the post-bourgeois proportion nearly triples.

Moreover, we do find something resembling a modified L-shaped curve in the distribution of these responses: across the six national samples, by far the biggest discontinuity occurs as we move from the second-youngest to the youngest cohort. Even among the 25-34 yearold cohort, there is still a heavy plurality of acquisitive types over post-bourgeois types. A major shift occurs as we move to the one age cohort that has been socialized entirely in the postwar era: ${ }^{18}$ the post-bourgeois group almost doubles in size (among the Continental samples), while the acquisitive group declines sharply. Within the youngest cohort, the postbourgeois group has either reached approximate parity or moved ahead of the acquisitive group-except in Britain. Although value change occurs across the whole range of age

${ }^{25}$ Interestingly, this shift corresponds to the transition from the purportedly apolitical youth of the 1950'stho "Skeptical Generation" or "Uncommitted Youth," as they were called-to the relatively radical youth of the 1960 's. cohorts, no transition is as sharp as the one associated with socialization in the postwar era.

Moving to cross-national comparisons, we note that our second prediction is also confirmed: Although the British sample as a whole has the smallest proportion of post-bourgeois types, among the cohorts who reached adulthood before World War II (those now more than 54 years of age), Britain shows the highest proportion of post-bourgeois respondents. She is very closely followed by the Dutch in this respect (the nationality which came closest to the British level of affluence in the prewar period).

Our third prediction also seems to be confirmed by the data: the rate of change across the British cohorts is much smaller than that found in any other country. The total number of points separating the oldest British cohort from the youngest is not much more than half as large as the range found in the German and Italian samples-where apparent intergenerational change is strongest (in keeping with our ffth prediction).

Our fourth prediction was that among the youngest cohorts, Britain should rank behind every country except Italy in her proportion of post-bourgeois respondents. This expectation is amply borne out: the British sample ranks far behind all the other samples-including the Italian, which seems to be a good deal more post-bourgeois than it should be on the basis of economic expectations. We will not attempt to provide an ad hoc explanation for this anomaly: It is puzzling, but on the whole the empirical findings seem to correspond to expectations drawn from economic history remarkably well.

\section{Generational or Life-Cycle Interpretation?}

At this point we should consider the possibility that the observed age-group differences reflect life-cycle factors, rather than intergenerational change. The large shift in value preferences which we find as we move from the sec- 
ond youngest to the youngest cohort is, indeed, what we would expect to find, on the basis of the conditions which governed the formative years of the respective cohorts. But the phenomenon might also be interpreted in life-cycle terms: the cutting point between the two age groups corresponds roughly to the age at which the average individual marries and starts a family. It could be argued, therefore, that the youngest cohort shows a tendency toward postbourgeois values merely because these individuals are young and lack family responsibilities; when they get older, they will have the same value priorities as the older cohorts have now. Since responses to these items seem to be relatively well integrated into the individual's attitudinal structure-a fact which suggests attitudinal stability-such an interpretation seens rather unlikely. The finding that the age-cohort differences seem to reflect the economic history of the given nation makes the life-cycle interpretation still less satisfactory. And when we examine the data from still another perspective, any simple life-cycle interpretation becomes quite implausible.

As we recall, my basic hypotheses predicted two sorts of effects associated with an ongoing transformation of value priorities. The first, which we have just examined, relates to age-cohort differences; the second relates to differing degrees of affluence. The hypotheses suggest that the degree of economic security an individual felt during bis formative years may play a key role in shaping his later political behavior. For most of our sample, it is impossible (at this late date) to obtain a direct measure of this variable. We do have some indirect indicators, however. Perhaps the most accurate one is the respondents' level of formal education: in Western Europe (even more than in the U.S.) one's likelihood of obtaining a secondary or university education is very closely related to the socioeconomic status of one's family of origin. Insofar as it influences levels of education and career aspirations, the relative affluence of one's parents also tends to be correlated with the individual's own economic status. To the extent that this association holds, our data on the individual's own education, current occupation, and income should also serve as a rough indicator of the degree to which he was economically secure during his formative years. (Most of the women in our sample do not have independent occupations: for them, our indicators are their own education and the occupation of bead of family.)

In terms of the indicators available to us, then, our prediction is that post-bourgeois values should be most prevalent among those who currently enjoy a relatively high socioeconomic status-although this indicator is understood to be important chiefly insofar as it reflects affluence during one's formative years. Let us test this hypothesis. Table 6 shows the distribution of value preferences according to socioeconomic status (ranked on the basis of a scale combining occupation and education). Table 6 summarizes the relationship between value priorities and socioeconomic status within the six national samples. As predicted, the lower socioeconomic groups are much more likely to select acquisitive value priorities than are the upper socioeconomic groups: overall, about 42 per cent of the lower socioeconomic category chooses the theoretically "pure" acquisitive value pair-more than double the proportion which makes that choice among the two highest socioeconomic categories. Conversely, the upper socioeconomic categories are much more likely to choose the post-bourgeois set of value priorities. Once again, Britain tends to be a deviant case: her social class differences (like her age-cohort differences) are smaller than those in the other countries.

On the whole, the relationship between age cohort and value priorities persists when we control for socioeconomic status (see Table 7). Despite the presence of some anomalies (especially in the Dutch sample), the predominant pattern is that the percentage choosing acquisi-

Table 6. Value Preferences by Socioeconomic Status

(Percentage choosing respective "pure" value pairs)

\begin{tabular}{|c|c|c|c|c|c|c|c|c|c|c|c|c|}
\hline \multirow{2}{*}{$\begin{array}{l}\text { Socioeconomic } \\
\text { Status }\end{array}$} & \multicolumn{2}{|c|}{ Netherlands } & \multicolumn{2}{|c|}{ Belgium } & \multicolumn{2}{|r|}{ Italy } & \multicolumn{2}{|c|}{ France } & \multicolumn{2}{|c|}{ Germany } & \multicolumn{2}{|c|}{ Britain } \\
\hline & Acq. & P-B N & Acq. & P-B N & Acq. & P-B N & Acq. & P-B N & Acq. & $\mathbf{P}-\mathbf{B} \mathbf{N}$ & Acg. & P-B N \\
\hline $\begin{array}{l}\text { Lower S.E.S. } \\
\text { Middle S.E.S. } \\
\text { Upper Middle S.ES. } \\
\text { Upper S.E.S. }\end{array}$ & $\begin{array}{l}40 \% \\
29 \\
16 \\
11\end{array}$ & $\begin{array}{l}7(551) \\
20(526) \\
30(365) \\
52(66)\end{array}$ & $\begin{array}{l}38 \\
33 \\
24 \\
17\end{array}$ & $\begin{array}{l}6(486) \\
15(353) \\
20(86) \\
35(95)\end{array}$ & $\begin{array}{l}38 \\
30 \\
18 \\
18\end{array}$ & $\begin{array}{l}10(995) \\
14(331) \\
32(105) \\
27(135)\end{array}$ & $\begin{array}{l}47 \\
35 \\
29 \\
14\end{array}$ & $\begin{array}{r}4(908) \\
11(626) \\
15(369) \\
42(143)\end{array}$ & $\begin{array}{l}49 \\
38 \\
23 \\
16\end{array}$ & $\begin{array}{rr}7 & (1319) \\
11 & (510) \\
26 & (139) \\
44 & (44)\end{array}$ & $\begin{array}{l}37 \\
40 \\
28 \\
25\end{array}$ & $\begin{array}{rr}6 & (1179) \\
8 & (459) \\
10 & (261) \\
15 & (73)\end{array}$ \\
\hline
\end{tabular}

- "Upper" S.E.S. Group includes respondents from "Modern Middle" class backgrounds having university educations (see footnote 9 for our definition of the "Modern Middle Class"); "Upper Middle" S.E.S. includes members of that class, having a secondary level of education; "Middle" S.E.S. includes respondents from other occupational backgrounds (including traditional middle class) educated beyond the primary level. 
tive priorities declines sharply, and the percentage choosing post-bourgeois priorities rises sharply, as we move from oldest to youngest cohorts. Perhaps the most significant aspect of Table 7 is the extent to which it tends to refute a life-cycle interpretation of the observed agegroup differences; to uphold such an interpretation, we would have to posit the existence of totally different life cycles for working-class and middle-class respondents. To be sure, working-class youth tend to enter the work force and marry earlier than their middle-class peers-but in terms of value priorities, the two classes are out of phase not just by four or five years, but by nearly a generation. Within the youngest Dutch cohort, for example, the upper socioeconomic categories choose post-bourgeois priorities over acquisitive priorities by a ratio of 50:6, while 43 per cent of their lower socioeconomic peers choose acquisitive values-with none making post-bourgeois choices. In the Belgian sample, the corresponding ratios are $35: 12$ within the upper middle and upper socioeconomic categories, as contrasted with 14: 24 within the lower socioeconomic category.
On the basis of value priorities, a working-class Frenchman 20 years old corresponds to a middle-class Frenchman in his 50's. More or less the same thing can be said in regard to the other samples from the countries of the European Community.

The age-cohort variations shown in Table 7 , then, can scarcely be explained as a result of the aging process alone. An explanation in terms of economic and physical security during a formative period accounts for the observed pattern of both age cohort and socioeconomic status differences in a parsimonious fashion. For this interpretation to be applicable, however, we must accept the hypothesis that these value priorities reflect an aspect of the individual's orientation which tends to persist over time.

Substantial age-cohort differences also persist when we apply finer controls for education by itself (see Table 8). Thus, although formal education seems to have a strong influence on the value priorities held by an individual, the agecohort differences, are not simply due to the different levels of education characterizing given age cohorts (as shown in Table 1). Mal-

Table 7. Value Preferences by Age Cohort, Controlling for Socioeconomic Status

(Percentage choosing respective "pure" value pairs)

\begin{tabular}{|c|c|c|c|c|c|c|}
\hline \multicolumn{7}{|c|}{ Britain } \\
\hline \multirow{2}{*}{$\begin{array}{l}\text { Age range } \\
\text { of cohort } \\
\text { in } 1970\end{array}$} & \multicolumn{3}{|c|}{ "Acquisitive" value preferences } & \multicolumn{3}{|c|}{ "Post-Bourgeois" value preferences } \\
\hline & $\begin{array}{l}\text { Lower } \\
\text { S.E.S. } \\
(\mathbf{N}=1179)\end{array}$ & $\begin{array}{l}\text { Middle } \\
\text { S.E.S. } \\
(\mathrm{N}=459)\end{array}$ & $\begin{array}{c}\text { Upper-Mid. \& } \\
\text { Upper S.E.S. } \\
(\mathrm{N}=334)\end{array}$ & $\begin{array}{l}\text { Lower } \\
\text { S.E.S. } \\
(\mathrm{N}=1179)\end{array}$ & $\begin{array}{c}\text { Middle } \\
\text { S.E.S. } \\
(\mathrm{N}=459)\end{array}$ & $\begin{array}{c}\text { Upper-Mid. \& } \\
\text { Upper S.E.S. } \\
(\mathbf{N}=334)\end{array}$ \\
\hline $16-24$ & $26 \%$ & 31 & 19 & $10 \%$ & 19 & 16 \\
\hline $25-34$ & 24 & 35 & 34 & 10 & 7 & 8 \\
\hline $35-44$ & 25 & 43 & 29 & 7 & 7 & 10 \\
\hline $45-54$ & 38 & 43 & 25 & 4 & 8 & 4 \\
\hline $55-64$ & 44 & 40 & 33 & 6 & 8 & 14 \\
\hline $65+$ & 50 & 54 & $(34)^{*}$ & 5 & 3 & (14) \\
\hline \multicolumn{7}{|c|}{ Germany } \\
\hline \multirow{2}{*}{$\begin{array}{l}\text { Age range } \\
\text { of cohort } \\
\text { in } 1970\end{array}$} & \multicolumn{3}{|c|}{ "Acquisitive" value preferences } & \multicolumn{3}{|c|}{ "Post-Bourgeois" value preferences } \\
\hline & $\begin{array}{l}\text { Lower } \\
\text { S.E.S. } \\
(\mathrm{N}=1319)\end{array}$ & $\begin{array}{c}\text { Middle } \\
\text { S.E.S. } \\
(\mathrm{N}=510)\end{array}$ & $\begin{array}{c}\text { Upper-Mid. \& } \\
\text { Upper S.E.S. } \\
(\mathrm{N}=183)\end{array}$ & $\begin{array}{c}\text { Lower } \\
\text { S.E.S. } \\
(\mathrm{N}=1319)\end{array}$ & $\begin{array}{c}\text { Middle } \\
\text { S.E.S. } \\
(\mathrm{N}=510)\end{array}$ & $\begin{array}{c}\text { Upper-Mid. \& } \\
\text { Upper S.E.S. } \\
(\mathrm{N}=183)\end{array}$ \\
\hline $16-24$ & $25 \%$ & 20 & 10 & $15 \%$ & 19 & 49 \\
\hline $25-34$ & $40^{\circ}$ & 29 & 19 & 10 & 17 & 35 \\
\hline $35-54$ & 48 & 48 & 23 & 6 & 8 & 20 \\
\hline $45-54$ & 52 & 41 & 33 & 6 & 7 & 14 \\
\hline $55-64$ & 64 & 54 & $(32)^{*}$ & 3 & 6 & (16) \\
\hline $65+$ & 59 & 49 & (33) & 2 & 0 & (11) \\
\hline
\end{tabular}

* Percentages based on fewer than 30 cases are enclosed in parentheses. 
Table 7.-(Continued)

\begin{tabular}{|c|c|c|c|c|c|c|}
\hline \multicolumn{7}{|c|}{ France } \\
\hline \multirow{2}{*}{$\begin{array}{l}\text { Age range } \\
\text { of cohort } \\
\text { in } 1970\end{array}$} & \multicolumn{3}{|c|}{ "Acquisitive" value preferences } & \multicolumn{3}{|c|}{ "Post-Bourgeois" value preferences } \\
\hline & $\begin{array}{l}\text { Lower } \\
\text { S.E.S. } \\
(\mathrm{N}=908)\end{array}$ & $\begin{array}{l}\text { Middle } \\
\text { S.E.S. } \\
(N=626)\end{array}$ & $\begin{array}{c}\text { Upper-Mid. \& } \\
\text { Upper S.E.S. } \\
(\mathrm{N}=512)\end{array}$ & $\begin{array}{l}\text { Lower } \\
\text { S.E.S. } \\
(\mathrm{N}=908)\end{array}$ & $\begin{array}{c}\text { Middle } \\
\text { S.E.S. } \\
(\mathrm{N}=626)\end{array}$ & $\begin{array}{c}\text { Upper-Mid. \& } \\
\text { Upper S.E.S. } \\
(\mathrm{N}=512)\end{array}$ \\
\hline $16-24$ & $30 \%$ & 20 & 17 & $8 \%$ & 18 & 31 \\
\hline $25-34$ & 41 & 41 & 26 & 2 & 6 & 23 \\
\hline $35-44$ & 45 & 36 & 24 & 6 & 17 & 17 \\
\hline $45-54$ & 49 & 26 & 32 & 4 & 10 & 24 \\
\hline $55-64$ & 53 & 40 & 36 & 5 & 9 & 8 \\
\hline $65+$ & 49 & 56 & 31 & 1 & 4 & 5 \\
\hline
\end{tabular}

Italy

\begin{tabular}{|c|c|c|c|c|c|c|}
\hline \multirow{2}{*}{$\begin{array}{l}\text { Age range } \\
\text { of cohort } \\
\text { in } 1970\end{array}$} & \multicolumn{3}{|c|}{ "Acquisitive" value preferences } & \multicolumn{3}{|c|}{ "Post-Bourgeois" value preferences } \\
\hline & $\begin{array}{c}\text { Lower } \\
\mathrm{S} . \mathrm{E} . \mathrm{S} \text {. } \\
(\mathrm{N}=995)\end{array}$ & $\begin{array}{c}\text { Middle } \\
\text { S.E.S. } \\
(\mathrm{N}=331)\end{array}$ & $\begin{array}{c}\text { Upper-Mid. \& } \\
\text { Upper S.E.S. } \\
(\mathrm{N}=240)\end{array}$ & $\begin{array}{l}\text { Lower } \\
\text { S.E.S. } \\
(\mathrm{N}=995)\end{array}$ & $\begin{array}{l}\text { Middle } \\
\text { S.E.S. } \\
(\mathrm{N}=331)\end{array}$ & $\begin{array}{l}\text { Upper-Mid. \& } \\
\text { Upper S.E.S. } \\
(\mathrm{N}=240)\end{array}$ \\
\hline $\begin{array}{l}16-24 \\
25-34 \\
35-44 \\
45-54 \\
55-64 \\
65+\end{array}$ & $\begin{array}{l}23 \% \\
31 \\
36 \\
38 \\
46 \\
53\end{array}$ & $\begin{array}{c}17 \\
26 \\
30 \\
39 \\
44 \\
(46)\end{array}$ & $\begin{array}{l}9 \\
13 \\
25 \\
24 \\
(12)^{*} \\
(83)\end{array}$ & $\begin{array}{c}23 \% \\
11 \\
9 \\
8 \\
7 \\
4\end{array}$ & $\begin{array}{r}25 \\
7 \\
15 \\
7 \\
13 \\
(9)\end{array}$ & $\begin{array}{l}40 \\
37 \\
23 \\
19 \\
(5) \\
(0)\end{array}$ \\
\hline
\end{tabular}

Belgium

\begin{tabular}{|c|c|c|c|c|c|c|}
\hline \multirow{2}{*}{$\begin{array}{l}\text { Age range } \\
\text { of cohort } \\
\text { in } 1970\end{array}$} & \multicolumn{3}{|c|}{ "Acquisitive" value preferences } & \multicolumn{3}{|c|}{ "Post-Bourgeois" value preferences } \\
\hline & $\begin{array}{c}\text { Lower } \\
\text { S.E.S. } \\
(\mathrm{N}=486)\end{array}$ & $\begin{array}{c}\text { Middle } \\
\text { S.E.S. } \\
(\mathrm{N}=353)\end{array}$ & $\begin{array}{c}\text { Upper-Mid. \& } \\
\text { Upper S.E.S. } \\
\text { (N=181) }\end{array}$ & $\begin{array}{c}\text { Lower } \\
\text { S.E.S. } \\
(\mathrm{N}=486)\end{array}$ & $\begin{array}{l}\text { Middle } \\
\text { S.E.S. } \\
(\mathrm{N}=353)\end{array}$ & $\begin{array}{l}\text { Upper-Mid. \& } \\
\text { Upper S.E.S. } \\
(\mathrm{N}=181)\end{array}$ \\
\hline $16-24$ & $24 \%$ & 24 & 12 & $14 \%$ & 20 & 35 \\
\hline $25-34$ & 35 & 38 & 30 & 4 & 12 & 30 \\
\hline $35-44$ & 32 & 33 & 20 & 11 & 16 & 36 \\
\hline $45-54$ & 37 & 23 & 20 & 10 & 19 & 9 \\
\hline $55-64$ & 42 & 34 & 26 & 3 & 18 & 18 \\
\hline $65+$ & 41 & 58 & $(50)^{*}$ & 3 & 0 & (0) \\
\hline
\end{tabular}

Netherlands

\begin{tabular}{|c|c|c|c|c|c|c|}
\hline \multirow{2}{*}{$\begin{array}{l}\text { Age range } \\
\text { of cohort } \\
\text { in } 1970\end{array}$} & \multicolumn{3}{|c|}{ "Acquisitive" value preferences } & \multicolumn{3}{|c|}{ "Post-Bourgeois" value preferences } \\
\hline & $\begin{array}{c}\text { Lower } \\
\text { S.E.S. } \\
(\mathrm{N}=551)\end{array}$ & $\begin{array}{c}\text { Middle } \\
\text { S.E.S. } \\
(\mathrm{N}=526)\end{array}$ & $\begin{array}{c}\text { Upper-Mid. \& } \\
\text { Upper S.E.S. } \\
(\mathrm{N}=431)\end{array}$ & $\begin{array}{l}\text { Lower } \\
\text { S.E.S. } \\
(N=551)\end{array}$ & $\begin{array}{l}\text { Middle } \\
\text { S.E.S. } \\
(\mathrm{N}=526)\end{array}$ & $\begin{array}{l}\text { Upper-Mid. \& } \\
\text { Upper S.E.S. } \\
(\mathrm{N}=431)\end{array}$ \\
\hline $16-24$ & $43 \%$ & 23 & 6 & $0 \%$ & 28 & 50 \\
\hline $25-34$ & 36 & 29 & 12 & 11 & 15 & 28 \\
\hline $35-44$ & 43 & 32 & 20 & 8 & 16 & 28 \\
\hline $45-54$ & 36 & 18 & 25 & 5 & 25 & 25 \\
\hline $55-64$ & 46 & 49 & 24 & 10 & 6 & 19 \\
\hline $65+$ & 40 & $(61)^{*}$ & (13) & 7 & (0) & (13) \\
\hline
\end{tabular}

* Percentages based on fewer than 30 cases are enclosed in parentheses. 
Table 8. Value Choices by Age Cohort, Controlling for Education

(Percentage choosing acquisitive or post-bourgeois pairs)

\begin{tabular}{|c|c|c|c|c|c|c|c|c|c|}
\hline \multirow{2}{*}{ Age in 1970} & \multicolumn{3}{|c|}{ Primary } & \multicolumn{3}{|c|}{ Secondary } & \multicolumn{3}{|c|}{ University } \\
\hline & Acq. & P-B & $N$ & Acq. & P-B & $\mathrm{N}$ & Acq. & P-B & $\mathbf{N}$ \\
\hline $\begin{array}{l}\text { Britain } \\
\qquad \begin{array}{l}16-24 \\
25-34 \\
35-44 \\
45-54 \\
55-64 \\
65+\end{array} \\
\text { Spread, from youngest to oldest cohort: }\end{array}$ & $\begin{array}{l}26 \% \\
27 \\
28 \\
40 \\
42 \\
50 \\
+24\end{array}$ & $\begin{array}{r}12 \\
9 \\
6 \\
5 \\
6 \\
4 \\
-8\end{array}$ & $\begin{array}{l}(121) \\
(216) \\
(205) \\
(299) \\
(267) \\
(315)\end{array}$ & $\begin{array}{l}25 \% \\
34 \\
33 \\
30 \\
40 \\
48 \\
+23\end{array}$ & $\begin{array}{r}16 \\
5 \\
12 \\
6 \\
9 \\
4 \\
-12\end{array}$ & $\begin{array}{l}(73) \\
(89) \\
(57) \\
(67) \\
(45 j \\
(23)\end{array}$ & $\begin{array}{r}21 \% \\
21 \\
38 \\
18 \\
33 \\
31 \\
+10\end{array}$ & $\begin{array}{r}19 \\
21 \\
13 \\
0 \\
22 \\
23 \\
+\quad 4\end{array}$ & $\begin{array}{l}(48) \\
(19) \\
(8) \\
(11) \\
(9) \\
(13)\end{array}$ \\
\hline Spread: & $\begin{array}{l}25 \% \\
36 \\
49 \\
50 \\
63 \\
59 \\
+34\end{array}$ & $\begin{array}{r}15 \\
12 \\
6 \\
7 \\
4 \\
2 \\
-13\end{array}$ & $\begin{array}{l}(235) \\
(353) \\
(330) \\
(278) \\
(278) \\
(213)\end{array}$ & $\begin{aligned} & 11 \% \\
& 28 \\
& 29 \\
& 31 \\
& 35 \\
& 44 \\
&+33\end{aligned}$ & $\begin{array}{r}36 \\
31 \\
21 \\
3 \\
7 \\
0 \\
-36\end{array}$ & $\begin{array}{l}(47) \\
(36) \\
(28) \\
(29) \\
(29) \\
(27)\end{array}$ & $\begin{array}{r}7 \% \\
18 \\
17 \\
18 \\
25 \\
20 \\
+13\end{array}$ & $\begin{array}{r}61 \\
47 \\
33 \\
27 \\
25 \\
20 \\
-41\end{array}$ & $\begin{array}{l}(28) \\
(17) \\
(6) \\
(11) \\
(8) \\
(5)\end{array}$ \\
\hline Spread: & $\begin{aligned} & 30 \% \\
& 39 \\
& 46 \\
& 45 \\
& 52 \\
& 49 \\
&+19\end{aligned}$ & $\begin{array}{r}11 \\
2 \\
8 \\
4 \\
5 \\
1 \\
-10\end{array}$ & $\begin{array}{l}(84) \\
(145) \\
(170) \\
(188) \\
(184) \\
(249)\end{array}$ & $\begin{array}{r}21 \% \\
40 \\
27 \\
32 \\
41 \\
55 \\
+34\end{array}$ & $\begin{array}{r}17 \\
9 \\
14 \\
17 \\
8 \\
3 \\
-14\end{array}$ & $\begin{array}{l}(224) \\
(172) \\
(139) \\
(112) \\
(74) \\
(88)\end{array}$ & $\begin{array}{r}6 \% \\
6 \\
22 \\
15 \\
35 \\
35 \\
+29\end{array}$ & $\begin{array}{r}48 \\
48 \\
39 \\
39 \\
10 \\
5 \\
-43\end{array}$ & $\begin{array}{l}(52) \\
(50) \\
(36) \\
(13) \\
(20) \\
(20)\end{array}$ \\
\hline Spread: & $\begin{array}{l}23 \% \\
33 \\
37 \\
38 \\
44 \\
53 \\
+30\end{array}$ & $\begin{array}{r}23 \\
9 \\
9 \\
10 \\
7 \\
7 \\
4 \\
-19\end{array}$ & $\begin{array}{l}(199) \\
(183) \\
(326) \\
(264) \\
(278) \\
(168)\end{array}$ & $\begin{array}{l}18 \% \\
29 \\
28 \\
43 \\
17 \\
60 \\
+42\end{array}$ & $\begin{array}{r}25 \\
21 \\
17 \\
14 \\
17 \\
20 \\
-\quad 5\end{array}$ & $\begin{array}{l}(44) \\
(24) \\
(18) \\
(14) \\
(12) \\
(5)\end{array}$ & $\begin{array}{r}7 \% \\
14 \\
24 \\
15 \\
20 \\
75 \\
+67\end{array}$ & $\begin{array}{r}39 \\
40 \\
24 \\
15 \\
0 \\
0 \\
-39\end{array}$ & $\begin{array}{l}(87) \\
(35) \\
(41) \\
(20) \\
(15) \\
(8)\end{array}$ \\
\hline Spread: & $\begin{array}{l}26 \% \\
41 \\
29 \\
33 \\
43 \\
43 \\
+17\end{array}$ & $\begin{array}{r}19 \\
3 \\
9 \\
8 \\
4 \\
3 \\
-16\end{array}$ & $\begin{array}{l}(27) \\
(63) \\
(98) \\
(89) \\
(126) \\
(179)\end{array}$ & $\begin{array}{c}19 \% \\
31 \\
30 \\
28 \\
23 \\
52 \\
+33\end{array}$ & $\begin{array}{r}23 \\
14 \\
21 \\
21 \\
15 \\
0 \\
-23\end{array}$ & $\begin{array}{l}(147) \\
(117) \\
(106) \\
(80) \\
(60) \\
(29)\end{array}$ & $\begin{array}{r}14 \% \\
32 \\
17 \\
8 \\
50 \\
40 \\
+26\end{array}$ & $\begin{array}{r}41 \\
36 \\
50 \\
0 \\
20 \\
0 \\
-41\end{array}$ & $\begin{array}{l}(44) \\
(25) \\
(24) \\
(12) \\
(10) \\
(10)\end{array}$ \\
\hline Netherlands & $\begin{array}{r}35 \% \\
35 \\
41 \\
32 \\
42 \\
42 \\
+\quad 7\end{array}$ & $\begin{array}{r}0 \\
10 \\
7 \\
8 \\
7 \\
6 \\
+6\end{array}$ & $\begin{array}{l}(40) \\
(100) \\
(122) \\
(113) \\
(82) \\
(81)\end{array}$ & $\begin{array}{r}16 \% \\
19 \\
27 \\
23 \\
35 \\
52 \\
+36\end{array}$ & $\begin{array}{r}36 \\
19 \\
21 \\
24 \\
13 \\
0 \\
-36\end{array}$ & $\begin{array}{l}(258) \\
(173) \\
(146) \\
(79) \\
(48) \\
(21)\end{array}$ & $\begin{array}{r}0 \% \\
10 \\
19 \\
11 \\
13 \\
33 \\
+33\end{array}$ & $\begin{array}{r}58 \\
52 \\
48 \\
56 \\
25 \\
17 \\
-41\end{array}$ & $\begin{array}{l}(19) \\
(21) \\
(21) \\
(9) \\
(9) \\
(6)\end{array}$ \\
\hline
\end{tabular}


tiple classification analyses ${ }^{19}$ indicate that education is among the strongest predictors of value priorities. It ranks with occupation, religion, income levels, and age cohort as an important influence on basic values (although all four of the latter variables also seem to have substantial independent effects on value priorities, when we control for the effects of each of the other variables). Our own interpretation would emphasize that this is the case because education is our most accurate indicator of parental affluence during the respondent's formative years. It might very plausibly be argued, however, that this relatively strong relationship exists because of something based on education itself: for example, that under present circumstances, the process of formal education assimilates the individual into an elite political culture which stresses expressive values.20 Indeed, we suspect that there may be some truth in the latter interpretation; but we regard it as a complementary rather than an alternative explanation. Our data do not contain a direct measure of economic security during one's formative years, so we cannot separate the two effects. But regardless of whether we regard the impact of education as being largely due to education per $s e$, or a reflection of parental affluence, two important facts seem fairly clear: (1) the age-cohort differences are not due to educational differences alone-even the less educated members of the younger cohorts show a marked tendency to be less acquisitive and more postbourgeois than the older cohorts (which may reflect the fact that in the postwar era, even the less educated have known relative affuence). (2) Even if the socioeconomic class differences are largely due to education per se rather than to affluence during formative years, we would expect them to persist over time: relatively high levels of formal education are a stable characteristic of the younger cohorts, which is not likely to disappear as the individuals age. In either case, we may be justified, therefore, in projecting changes over time as the younger (and more educated) cohorts re-

\footnotetext{
${ }^{10}$ This analysis is similar to a multiple regression analysis, using dummy variables. For an explanation of the technique, see John A. Sonquist, Multivariate Model Building: the Validation of a Search Strategy (Ann Arbor: Institute for Social Research, 1970).

${ }_{20}$ Granting that this is the process at work, we must ask why this elite political culture gives relatively high priority to expressive values; one is tempted to draw on relative economic security to supply at least part of the answer. As is pointed out later in this section, however, higher education does not seem to be inherently linked with a libertarian political position; at other points in history, it has been associated with relatively authoritarian and conservative positions.
}

Table 9. Percentage Choosing "Freedom of Speech" by Age Group: Germany, 1962*

\begin{tabular}{ll}
\hline Age in 1962 & \\
\hline $16-25$ & $58 \%$ \\
$25-30$ & 52 \\
$30-50$ & 50 \\
$50-65$ & 40 \\
$65+$ & 34 \\
\hline
\end{tabular}

* Source: EMNID Pressedienst (Gallup-Institut, Bielefeld), cited in Encounter, Vol. 22, No. 4 (April, 1964), p. 53. Age groupings are those given in this source.

place the older groups in the adult electorate.

Ultimately, of course, our thesis can be proved or disproved only with the aid of longitudinal data-and, as we noted earlier, very little is available at present. A small body of relevant time-series data is available, however, and it seems worth examining. The EMNID institute of West Germany employed an item concerning value priorities in a series of surveys of German public opinion from 1949 through 1963; the question was, "Which of the Four Freedoms do you personally consider most important?" Like the items used to measure value priorities in our own survey, this was a forcedchoice question, requiring the individual to make a selection among positively valued items, according to his personal priorities. And because the two leading choices by far were "Freedom from Want" and "Freedom of Speech," the choice an individual made probably tends to tap the dimension central to this inquiry-acquisitive versus post-bourgeois values. In 1962, for example, nearly half of the German sample ranked "Freedom of Speech" as the most important freedom. Let us look in Table 9 at the relationship between age and preference for that value in 1962 (unfortunately, the only year for which an age breakdown is available).

The pattern of age differences shown in Table 9 is similar to what we found in our own data: the young are much more likely to place a high priority on free speech than are the old. Prima facie, this age-relationship could be interpreted as reflecting either a life-cycle effect or intergenerational change. ${ }^{21}$

\footnotetext{
nOther possibilities also exist:
}

(1) It could be due to sampling error. We believe the latter possibility can be excluded, however: we have found a similar age-group pattern in all seven of the European surveys cited thus far; moreover, we have examined responses to items from a large number of American surveys which, implicitly or openly, ask the individual to choose between political liberties and 
The former interpretation bas a certain appeal: it is linked with the seemingly parsimonious assumption that nothing is really changing -young people will be like their parents when they get older. When examined a little more closely, it becomes apparent that the life-cycle interpretation is in no sense more parsimonious than the generational interpretation; indeed, it could be considered less so: though it assumes that the preferences of a nation as a whole will show no change, this result can be obtained only if each of the age-groups within the nation does change. Furthermore, it assumes-often without even considering the alternative-that the direction of any shift in preferences can be taken for granted: they must move in the direction which tends to erase the age-group differences. We agree it would be unrealistic to assume that individuals' value priorities will show no change over their adult lives-but it is conceivable that, as they age, they might move in the direction of giving a higher priority to libertarian values (for example), rather than a lower priority. Fortunately, we are able to examine trends in the percentages giving top priority to the item cited in Table 9. The EMNID institute's responses to the "Four Freedoms" item over the period 1949-1963 are reported in Table 10. The changes over time are impressive in size. These shifts might be attributed to two types of causes: 1) The mechanics of intergenerational change. This process has two aspects: (a) the recruitment of new (younger) members into the sampling universe from 1949 to 1963; and (b) mortality among members of the 1949 sample-most of the group aged 65+ in that year would have died off (its youngest members would be 79 in 1963). 2) Adult attitude change. The life-cycle effect constitutes a

threats to order or national security. A similar agegroup pattern occurs in virtually all of them. See, for example, Hazel Gaudet, "The Polls: Freedom of Speech," Public Opinion Quarterly, 34 (Fall, 1970). The same pattern occurs in responses to comparable items in the S.R.C. 1968 presidential election survey. The likelihood of finding such a pattern in so many surveys from post-industrial societies as a result of sampling error appears negligible.

(2) The age-group pattern might be due to differential birth rates or life-expectancies among social groups having distinctive value priorities. These would tend to give the group having the higher birth rate (or shorter life expectancy) a disproportionately strong representation among the younger cohorts. Empirically, lower income groups tend to have had higher birth rates and shorter life expectancies than upper income groups over recent decades (For example, see Butler and Stokes, op. cit., pp. 265-270). But lower income groups are relatively likely to express acquisitive value priorities. Despite this fact, postbourgeois values are relatively widespread among the younger cohorts!
Table 10. Changing Value Priorities: Germany, 1949-1963

"Which of the Four Freedoms do you personally consider most important?" (Percentage choosing given item)*

\begin{tabular}{lcccrr}
\hline & 1949 & 1954 & 1958 & 1962 & 1963 \\
\hline Freedom from Want & $35 \%$ & 35 & 28 & 17 & 15 \\
Freedom of Speech & 26 & 32 & 44 & 47 & 56 \\
Freedom from Fear & 17 & 17 & 10 & 8 & 10 \\
Freedom of Worship & 12 & 16 & 16 & 13 & 14 \\
N.A., D.K. & 10 & - & 2 & 15 & 5
\end{tabular}

* Source: EMNID Pressedienst, cited in Table 9.

special case of adult attitude change, which assumes (in this case) that individuals will become less libertarian and more economicallymotivated as they grow older.

The data from Tables 9 and 10 enable us to estimate parameters for the two processes. While rough calculations indicate that only about one-third of the observed shift in value priorities from 1949 to 1962 might be attributed to the recruitment/mortality process, the direction of the remaining adult attitude change runs directly counter to that predicted by the life-cycle interpretation. It seems clear that, insofar as a shift in priorities occurred among individuals who were in the sampling universe in both 1949 and 1962, they tended to move in the "post-bourgeois" direction as they agednot the reverse.

The time-series data reported in Table 10, moreover, has an excellent fit with recent German economic history. In the Germany of 1949, "Freedom from Want" was by far the leading choice. Germany's recovery from the devastation of World War II had just begun to get under way, and economic needs were extremely pressing for most of the population. Even under conditions of poverty, however, freedom of speech was the second-ranking choice. The fourteen years that followed were the years of the Wirtschaftswunder. Germany rose from poverty to plenty with almost incredible speed, and the two leading choices exchanged places: the percentage choosing "Freedom of Speech" more than doubled, while the percentage choosing "Freedom from Want" fell to less than half its former level (choice of the other two alternatives remaining relatively constant). These data suggest that a society may, indeed, show a shift in value priorities in response to changing conditions of scarcity. Admittedly, this must be regarded as an exceptional case: only rarely does so great a change in the average individual's economic situation 
Table 11. The University Crisis: Value Climates in Student Milieu v. Administrative Milieu

(Percentage choosing the respective "pure" value pairs within the 16-24 year-old cohort ["students"] and the 45-54 year-old cohort ["administrators"] of the upper-middle/upper S.E.S. category)

\begin{tabular}{|c|c|c|c|c|c|c|c|c|c|c|c|c|}
\hline & \multicolumn{2}{|c|}{ Britain } & \multicolumn{2}{|c|}{ Germany } & \multicolumn{2}{|c|}{ France } & \multicolumn{2}{|c|}{ Italy } & \multicolumn{2}{|c|}{ Belgium } & \multicolumn{2}{|c|}{ Netherlands } \\
\hline & Acq. & P-B & Acq. & P-B & Acq. & P-B & Acq. & P-B & Acq. & P-B & Acq. & P-B \\
\hline $\begin{array}{l}\text { Students' Milieu } \\
\text { Administrators' Milieu }\end{array}$ & $\begin{array}{r}19 \\
+\quad 25\end{array}$ & $\begin{array}{r}16 \\
4\end{array}$ & $\begin{array}{l}10 \\
33\end{array}$ & $\begin{array}{l}49 \\
14\end{array}$ & $\begin{array}{l}17 \% \\
32\end{array}$ & $\begin{array}{l}31 \\
24\end{array}$ & $\begin{array}{r}9 \\
24\end{array}$ & $\begin{array}{l}40 \\
19\end{array}$ & $\begin{array}{l}12 \\
20\end{array}$ & $\begin{array}{r}35 \\
9\end{array}$ & $25 \%$ & $\begin{array}{l}50 \\
25\end{array}$ \\
\hline
\end{tabular}

occur within so short a space of time. But the direction of movement clearly conforms to the expectations generated by our hypotheses.

Some fragmentary but interesting time-series evidence from the other side of the Atlantic might be drawn from two excellent studies of the political consciousness of Yale students. Each seems to be the result of penetrating observation: Robert Lane's Political Thinking and Consciousness; 22 and Kenneth Keniston's Young Radicals. ${ }^{23}$ The former study is based on material gathered in the 1950's and early 1960's; the latter study is based on observations made about ten years later. Being drawn from the same milieu with a decade's time-lag, they provide an impressionistic sort of time-series data. And the picture which emerges is one of profound change. Again and again in Lane's material one is made aware of the pressures toward conformity with a conservative norm: to be socially acceptable in the Yale of the late 50 's, one felt obliged to identify with the Republican Party and to support the policies of the Establishment. The situation a decade later shows a fascinating contrast. As Keniston makes clear, the "Young Radicals" who had then become a salient part of the Yale scene were not acting out of youthful rebellion: they were advocating policies which seemed to them a more faithful implementation of the values that had been inculcated in their homes. Yet their views sharply confiicted with the social and foreign policies of the popularly elected governments, whether Democratic or Republican. In another book which was shaped by observation of Yale students, Charles Reich gives an insightful interpretation of this complex process of change. ${ }^{2 \cdot 4}$ His analysis, in part, is similar to our own: a younger generation has emerged which has a basically different perspective from earlier generations (Reich refers to the younger generation's value system as "Consciousness

22 (Chicago: Markham Publishing Company, 1969).

${ }^{2 s}$ (New York: Harcourt, Brace and World, 1968).

${ }^{2}$ The Greening of America (New York: Random House, 1970).
III"). My conclusions diverge from those of Reich chiefly in the extent to which I would generalize these changes. The present data suggest that although post-industrial societies may indeed be undergoing a transformation similar to the emergence of "Consciousness III," the process of transformation is decidedly uneven, and the earlier types of consciousness continue to be predominant even among youth-except in certain sectors: above all, the universities.

A life-cycle interpretation tends to write off such evidence of intergenerational differences as due to youthful rebelliousness or high spirits, often without considering the type of values motivating radical youth. Although I am not aware of a body of micro-analytic data from Europe comparable to the Yale studies just cited, observation of political activity on a gross level suggests a significant change in the values espoused by European student activists during the past generation or so. One need scarcely dwell on the Rightist and authoritarian aspects of student movements in Germany and Italy of the 1930's. What is perhaps less widely recognized is that the predominant thrust of political activism among French students in the 1930's also bad a markedly conservative character: their most critical intervention in French politics undoubtedly took place in early 1934, when Monarchist and quasi-Fascist youth (mostly upper middle-class, and many of them from the universities) played a prominent role in a series of riots which very nearly overthrew the Third Republic. ${ }^{25}$ Then, as now, British students seem to have been a deviant case: relatively liberal in the 1930's and relatively conservative in 1970.

The wave of intense student political activity which swept both Europe and North America in the late 1960's seems to have diminished today. ${ }^{20}$ Was it a campus fad or does it represent

${ }^{25}$ See, for example, William L. Shirer, The Collapse of the Third Republic (New York: Simon \& Schuster, 1969), pp. 201-223.

${ }^{20}$ Among the reasons for this decline in activity, the fact that some concessions were made to some of 
a manifestation of broader changes in post-industrial society? I believe that the present data and analytic framework provide a useful perspective from which to interpret its implications.

To illustrate, let us look at Table 11 (which is simply a subset of Table 7). University students in these countries tend to be drawn overwhelmingly from the upper and upper-middle socioeconomic strata. If we take the youngest cohort of these strata as roughly indicative of the value climate in the student milieu in each country-and if we regard the 45-54 year-old cohort of the same socioeconomic category as indicative of the milieu from which the university administrators are drawn-we can form an idea of the contrasting value climates within the two milieux. ${ }^{27}$ Our data suggest that there have always been a certain number of people with the value priorities which we call postbourgeois, but that until recently they were a relatively small minority. Within the last decade they seem to have become relatively numerous-constituting a major political bloc in themselves; furthermore, they tend to be brought together as a group capable of setting the prevailing tone in an important institutional context-the universities. As Table 11 indicates, post-bourgeois types now seem to hold a heavy plurality over the traditionally predomi-

the student demands is probably the most obvious factor, but I suspect that its importance is overrated. Another reason is that major political confrontations along the acquisitive/post-bourgeois dimension are likely to be counterproductive for the latter group under current conditions: the acquisitives still seem to hold a heavy numerical predominance-as became increasingly apparent on both sides of the Atlantic by the end of the 1960's. Still another factor seems pertinent in America: the economic recession of 1970 may have drawn greater attention to economic considerations on the part of groups which had previously given them little notice. The conventional wisdom holds that economic troubles tend to help the traditional Left; paradoxically (but in keeping with our analysis of intergenerational change) we would expect them to tend to undermine the New Left.

${ }^{27}$ Except among the youngest cohort, we do not have a large enough number of university-educated respondents to permit reliable estimates of the responses of those who actually have university educations. Within the youngest cohort, we do have at least 30 student respondents from four of our six countries; they tend to be somewhat more post-bourgeois than other members of their age group and socioeconomic stratum, but only moderately so: they are, on the average, four percentage points less acquisitive and seven points more post-bourgeois than their peers in Table 11. This suggests that it is not principally the university milieu which accounts for their value priorities (although this seems to play a part) but the fact that the students are from the youngest and most affluent social categories. nant acquisitive types in the student milieu of five of our six national samples. While they may not yet constitute an absolute majority even in this setting, their preponderance over the acquisitive types may enable the post-bourgeois group to act as the leading influence on many of their "ambivalent" peers. By contrast with the student milieu, the value climate from which the administrators are drawn tends to contain a plurality of acquisitive over postbourgeois types. The administrators, moreover, are subject to relatively strong pressures from society as a whole-which tends to be far more conservative in its value priorities than are the administrators themselves. The result (rather frequently) is not simply disagreement, but conflicts which seem unamenable to compromise-because they are based on fundamentally different value priorities. (An incidental outcome seems to be the frequent rotation of university administrators.)

A notable exception to the foregoing pattern appears in the British sample, where there still seems to be a narrow plurality choosing acquisitive value priorities, even within the student milieu-a finding which may go far to explain the relative tranquility of the university scene in that country. While there have been a few relatively subdued uprisings at British universities in recent years, one can point to student explosions which dwarf them in every one of the five other countries.

According to our data, West Germany seems to be the country which has the greatest degree of intergenerational strain in her universities, with a 3:1 predominance of acquisitive values in the "administrative" milieu and a 5:1 predominance of post-bourgeois value choices in the "student" milieu. This may seem momentarily surprising, since France is clearly the country in which the most resounding student uprising to date has taken place. To be sure, our data indicate considerable intergenerational strain in France, as well, but it seems to be less extreme than in the German case. These facts serve to remind us that survey data cannot be interpreted without reference to the institutional and geographical context from which they are drawn. We would attribute the differing outcomes to structural factors: important manifestations of student discontent took place at a number of locations in Germany well before they occurred in France. But the high degree of educational and administrative centralization in France meant that when an explosion did take place in Paris, it was a crisis that engulfed the whole country.

The hypothesis of intergenerational change 
in value priorities (based on different levels of economic scarcity during a cohort's formative years) seems to have a good ft with a wide variety of evidence: with the attitudinal patterns of the respective age cohorts, and with those of given socioeconomic strata in samples from six nations; with the economic history of given nations and with cross-national differences in economic experience; and with what time-series data are available. It would be foolish to deny that individuals can and do change during their adult years. But if one's malleability is relatively great during preadult years and tends to decline thereafter, we would expect to find residues from formative experiences in the response patterns of the various adult cohorts. ${ }^{28}$ Weighing the evidence as a whole, it seems to me that our data do give a rather strong suggestion of intergenerational change.

\section{Value Priorities and Political Partisanship}

The patterns of value preferences outlined above may represent a potential force for longterm political change. They might encourage the development of new political parties, relatively responsive to emerging value cleavages. Or they might lead to a realignment of the social bases of existing political parties, making age an increasingly important basis of cleavage (during a transitional period) and eventually, perhaps, tending to reverse the traditional alignment of the working class with the Left, and the middle class with the Right. For, in terms of the value priorities discussed in this article, upper status respondents are far likelier than lower status respondents to support a set of post-bourgeois principles which seem more

33 In their analysis of British panel survey data gathered in 1963, 1964 and 1965, Butler and Stokes, op. cit., pp. 58-59, comment:

A theory of political 'senescence' as it is sometimes called, fits comfortably the more general belief that the attitudes of youth are naturally liberal or radical, while those of age are conservative. . . . In the 1960's Conservative strength tended to be weakest among those born in the 1920's and just before. Electors younger than this tended actually to be a little more Conservative than those who lay within the precincts of early middle age. This irregularity, although an embarrassment to any simple theory of conservatism increasing with age, can readily be reconciled with the concept that the conservation of established political tendencies is what increases with age ... we must ask not how old the elector is but when it was that he was young.

For an excellent example of age-cohort analysis based on data at the elite level, see Robert D. Putnam, "Studying Elite Political Culture: the Case of 'Ideology,'" American Political Science Review, 65 (September, 1971). Putnam finds evidence of significant intergenerational changes in basic political style among British and Italian politicians. compatible with parties of movement than with parties of order. Do we find any relationship between political party choice and our indicators of underlying value preferences? The respondents in each of our samples were asked:

"If there were a General Election tomorrow, for which party would you be most likely to vote?"

Responses to this question are cross-tabulated with the two "pure" value pairs in Table 12; the parties are ordered according to the conventional notion of a Left-Right continuum.

In the British sample, the differences we find are of moderate size, but they are in the expected direction: respondents choosing postbourgeois values are more likely to support the Labour Party than are acquisitive-type respondents; the intergroup diffcrences amounts to eight percentage points. The post-bourgeois group is also relatively likely to support the Liberal Party, and the relative gains for both other parties come at the expense of the Conservatives-who are supported by a solid majority of the acquisitives, but by a minority of the post-bourgeois group. A somewhat similar pattern appears in the Belgian data.

In all four of the other countries we find quite sizeable differences in the partisan preferences of the two groups, and the differences are consistently in the expected direction: within the Dutch sample, for example, post-bourgeois respondents are more likely to support the parties of the Left by a margin of 23 percentage points; they give heavier support to the parties traditionally considered to be of the Left by a spread of 26 points in Italy; and by a spread of 15 points in Germany ( 22 points if we view today's F.D.P. as a party of the Left, which in some respects seems to be the case).

In France, the differences are the most impressive of all: post-bourgeois respondents are more likely to support parties usually considered Leftist by a margin of 36 percentage points over the acquisitives. A solid majority (56 per cent) of the latter group supports the Gaullist U.D.R. and their allies, the R.I.; while, by contrast, a bare 16 per cent of the postbourgeois group supports the Gaullist coalition! Although it enjoys a wide plurality in the nation as a whole, the Gaullist coalition draws an almost insignificant minority of support from the group holding post-bourgeois value priorities. This finding tends to confirm our interpretation of the May Revolt mentioned earlierthat France's crisis of 1968 brought about a partial repolarization of the electorate according to underlying value preferences (with many working-class respondents shifting to the Gaul- 
Table 12. Political Party Choice by Value Preferences

(Percentage choosing given political party)

\begin{tabular}{|c|c|c|c|c|c|c|c|c|c|}
\hline \multirow{2}{*}{ Value Pref: } & \multicolumn{4}{|c|}{ Britain } & \multicolumn{5}{|c|}{ Germany } \\
\hline & Labour & Liberal & Conserv. & $\mathbf{N}$ & SPD & FDP & CDU/CSU & NPD & $N$ \\
\hline \multirow[t]{3}{*}{$\begin{array}{l}\text { Acquisitive } \\
\text { Post-Bourg. } \\
\text { Difference: }\end{array}$} & $\begin{array}{r}37 \% \\
45 \\
+8 \\
\end{array}$ & $\begin{array}{r}7 \\
9 \\
+\quad 2 \\
\end{array}$ & $\begin{array}{r}57 \\
46 \\
-11 \\
\end{array}$ & $\begin{array}{l}(570) \\
(126)\end{array}$ & $\begin{array}{r}48 \% \\
63 \\
+15 \\
\end{array}$ & $\begin{array}{r}5 \\
12 \\
+7 \\
\end{array}$ & $\begin{array}{r}46 \\
23 \\
-\quad 23 \\
\end{array}$ & $\begin{array}{l}2 \\
2\end{array}$ & $\begin{array}{l}(648) \\
(164)\end{array}$ \\
\hline & \multicolumn{4}{|c|}{ France } & \multicolumn{5}{|c|}{ Italy } \\
\hline & Left & Center & $\begin{array}{l}\text { UDR, } \\
\text { RI }\end{array}$ & $\mathrm{N}$ & Left & $\begin{array}{l}\text { DC, } \\
\text { PRI }\end{array}$ & Liberal & $\begin{array}{c}\text { Extreme } \\
\text { Right }\end{array}$ & $\mathrm{N}$ \\
\hline \multirow[t]{3}{*}{$\begin{array}{l}\text { Acquisitive } \\
\text { Post-Bourg. } \\
\text { Difference: }\end{array}$} & $\begin{array}{r}34 \% \\
70 \\
+36\end{array}$ & $\begin{array}{r}10 \\
15 \\
+5\end{array}$ & $\begin{array}{r}56 \\
16 \\
-40\end{array}$ & $\begin{array}{l}(533) \\
(170)\end{array}$ & $\begin{aligned} & 28 \% \\
& 54 \\
&+26\end{aligned}$ & $\begin{array}{r}56 \\
38 \\
-18\end{array}$ & $\begin{array}{l}8 \\
8\end{array}$ & $\begin{array}{r}9 \\
-\quad 8\end{array}$ & $\begin{array}{l}(398) \\
(168)\end{array}$ \\
\hline & \multicolumn{4}{|c|}{ Belgium } & \multicolumn{5}{|c|}{ Netherlands } \\
\hline & Socialist & $\begin{array}{c}\text { Liberal } \\
\text { (PLP) }\end{array}$ & $\begin{array}{l}\text { Christian } \\
\text { Social }\end{array}$ & $\mathbf{N}$ & $\begin{array}{l}\text { Socialist, } \\
\text { Dem. '66 }\end{array}$ & & Liberal & $\begin{array}{l}\text { Confes- } \\
\text { sional }\end{array}$ & $\mathrm{N}$ \\
\hline $\begin{array}{l}\text { Acquisitive } \\
\text { Post-Bourg. } \\
\text { Difference: }\end{array}$ & $\begin{array}{r}31 \% \\
38 \\
+\quad 7\end{array}$ & $\begin{array}{r}13 \\
26 \\
+13\end{array}$ & $\begin{array}{r}56 \\
37 \\
-19\end{array}$ & $\begin{array}{l}(253) \\
(117)\end{array}$ & $\begin{array}{r}46 \% \\
69 \\
+23\end{array}$ & & $\begin{array}{r}12 \\
14 \\
+\quad 2\end{array}$ & $\begin{array}{r}43 \\
17 \\
-\quad 26\end{array}$ & $\begin{array}{l}(315) \\
(216)\end{array}$ \\
\hline
\end{tabular}

list side, while post-bourgeois elements from the middle class shifted to the Left). This sudden shift in vote from 1967 to 1968 does not seem to have been simply a temporary reaction to the 1968 crisis, with the voters returning to their normal partisan allegiance after the emergency had faded away. On the contrary, the French electorate still seems to retain an unequalled degree of political polarization according to value preferences in 1970, nearly two years after the May Revolt. This interpretation tends to be supported by data from a panel survey reported elsewhere. ${ }^{29}$ The apparently enduring nature of this redistribution of political positions, once it has taken place, suggests that it may, indeed, correspond to relatively deepseated values. In this connection, it seems significant that the other two countries in our survey which have experienced the most massive New Left upheavals (Germany and Italy) also show relatively high degrees of polarization ac-

20 Philip Converse and Roy Pierce noted a sizeable shift to the Right from 1967 to 1968 , within a panel of respondents asked to rank themselves on a LeftRight continuum in both years. After re-interviewing these respondent a third time, they report that more than 99 per cent of the change from 1967 to 1968 was preserved in 1969. See Converse and Pierce, "Basic Cleavages in French Politics and the Disorders of May and June, 1968," paper presented at the 7th World Congress of Sociology, Varna, Bulgaria, September, 1970. cording to value priorities, although its magnitude remains smaller than what we find in France. By contrast, Great Britain (apart from ethnic conflicts in Northern Ireland) has probably had the greatest measure of domestic tranquility among these countries in recent yearsand shows a relatively weak relationship between value priorities and political party choice.

Admittedly, we have not mapped out in any precise fashion the differences between the political goals of the acquisitive and post-bourgeois groups: the latter group may still be in the process of defining a program. Moreover, there is at least an equal lack of precision in the party labels which we have just employed: we regard "Left" and "Right" as merely convenient shorthand terms under which to group (for cross-national comparisons) two sets of parties which tend to differ in being relatively conservative or relatively change-oriented, but which otherwise vary a good deal from country to country. To be sure, the acquisitive and post-bourgeois types of respondents do seem to react quite differently to these two sets of parties, and the pattern is fairly consistent cross-nationally. But the cleavage is not one which runs neatly along the traditional Left-Right dimension. Perhaps for this reason political polarization according to un- 
derlying value preferences seems much more pronounced in relation to what might be called New Left parties (in countries where they exist) than in relation to what might be called the Traditional Left. To illustrate, let us take a closer look at the vote for certain small parties which seem to have a distinctive appeal for the post-bourgeois constituency (see Table 13).

In the French case, the PSU emerged from the crisis of May and June, 1968, as the political embodiment of the New Left, the only significant party which had unambiguously endorsed the May Revolt. Although it polled only 4 per cent of the vote nationally, and is supported by only 2 per cent of the acquisitives in our sample, it draws far more than this share of support among the postbourgeois constituency-getting fully 29 per cent of this group's preferences. By comparison, the other parties of the French Left enjoy only a relatively small advantage among the post-bourgeois group-getting 9 percentage points more support there than among the acquisitive constituency. A similar pattern applies to support for two other parties which might be said to have a more or less New Left coloring: Demokraten ' 66 in The Netherlands and the P.S.I.U.P. in Italy. The post-bourgeois group shows a marked preference for these parties, over the other parties conventionally regarded as of the Left. $^{30}$

${ }^{30}$ In the Italian case, however, the Communist party also seems to enjoy a relative preference within the post-bourgeois constituency: the PCI and PSIUP combined are supported by seven per cent of the acquisitives and by 30 per cent of the post-bourgeois group (leaving the two Socialist parties only a slightly greater proportion of support from the post-bourgeois group than from the acquisitives). It appears, then,
When we turn to the Belgian case, we find a rather surprising phenomenon. In traditional terms, we probably would not view the Belgian separatist parties as characteristically of the Left at all. But in their basis of recruitment, these parties (both Flemish and Walloon, but predominately the former) play a role comparable to that played by the PSU in France: they draw their strength very disproportionately from the post-bourgeois types, rather than from the acquisitives. In France, the ratio is nearly $15: 1$; in Belgium there is nearly a $4: 1$ over-representation of post-bourgeois as compared with acquisitive types. Indeed, when we include the separatist parties in our analysis, the Belgian Socialists actually show a slight deficit among the post-bourgeois group, when compared with the acquisitives (in Table 13).

The "New Left" parties and the Belgian separatists might seem to have little in common, other than a radical opposition to fundamental aspects of the established social system. But this disparity of political goals, juxtaposed with an apparent similarity in social bases and underlying value preferences, leads us back to a suggestion about the nature of post-bourgeois politics which was mentioned earlier: an important latent function may be to satisfy the need for belongingness. According to Maslow, this need comes next on the individual-level hierarchy, after needs related to sustenance and safety have been fulfilled. I would acknowledge and emphasize the importance of the manifest goals of a given movement in a given context; but it

that members of our Italian sample react to the PCI almost as if it were a New Left party-an interesting finding, in view of the fact that support for the French Communist party does not show a similar pattern; one wonders if the PCF cut itself off from postbourgeois support in repudiating the May Revolt.

Table 13. Political Party Choice by Value Preferences: Effect of the New Left and Belgian Separatist Parties

(Percentage choosing given political party)

\begin{tabular}{|c|c|c|c|c|c|c|c|c|c|c|}
\hline \multirow{2}{*}{$\begin{array}{l}\text { Value } \\
\text { Pref: }\end{array}$} & \multicolumn{4}{|c|}{ France } & \multicolumn{6}{|c|}{ Italy } \\
\hline & $\begin{array}{l}\text { Other } \\
\text { Left }\end{array}$ & Center & $\begin{array}{c}\text { UDR, } \\
\text { RI }\end{array}$ & $\mathbf{N}$ & PSIUP & $\begin{array}{c}\text { Other } \\
\text { Left }\end{array}$ & DC, PRI & Liberal & $\begin{array}{c}\text { Extreme } \\
\text { Right }\end{array}$ & $\mathbf{N}$ \\
\hline $\begin{array}{lr}\text { Acquisitive } & 2 \% \\
\text { Post-Bourg. } \quad 29 \\
\text { Difference: }+27\end{array}$ & $\begin{array}{r}32 \\
41 \\
+9\end{array}$ & $\begin{array}{r}10 \\
15 \\
+5\end{array}$ & $\begin{array}{r}56 \\
16 \\
-40\end{array}$ & $\begin{array}{l}(533) \\
(170)\end{array}$ & $\begin{array}{r}1 \% \\
+6\end{array}$ & $\begin{array}{r}26 \\
47 \\
+21\end{array}$ & $\begin{array}{r}56 \\
38 \\
-18\end{array}$ & $\begin{array}{l}8 \\
8\end{array}$ & $\begin{array}{r}9 \\
1 \\
-8\end{array}$ & $\begin{array}{l}(398) \\
(168)\end{array}$ \\
\hline \multirow{2}{*}{ Value Pref: } & \multicolumn{4}{|c|}{ Netherlands } & & \multicolumn{5}{|c|}{ Belgium } \\
\hline & Dem. '66 & Socialist & Lib. & $\begin{array}{l}\text { Confes- } \\
\text { sional }\end{array}$ & $\mathbf{N}$ & $\begin{array}{l}\text { Sep- } \\
\text { aratist }\end{array}$ & Socialist & Liberal & $\begin{array}{l}\text { Christian } \\
\text { Social }\end{array}$ & $\mathbf{N}$ \\
\hline $\begin{array}{l}\text { Acquisitive } \\
\text { Post-Bourg. } \\
\text { Difference: }\end{array}$ & $\begin{array}{l}13 \% \\
38 \\
+25\end{array}$ & $\begin{array}{r}32 \\
31 \\
-\quad 1\end{array}$ & $\begin{array}{r}11 \\
14 \\
+\quad 3\end{array}$ & $\begin{array}{r}43 \\
17 \\
-26\end{array}$ & $\begin{array}{l}(315) \\
(216)\end{array}$ & $\begin{array}{r}10 \% \\
36 \\
+26\end{array}$ & $\begin{array}{r}28 \\
24 \\
-\quad 4\end{array}$ & $\begin{array}{r}12 \\
16 \\
+4\end{array}$ & $\begin{array}{r}50 \\
23 \\
-27\end{array}$ & $\begin{array}{l}(271) \\
(128)\end{array}$ \\
\hline
\end{tabular}


also seems likely that protest movements which are in radical conflict with their environment provide their members with a sense of belongingness. In the midst of large, anonymous, bureaucratically-organized societies, these movements may become tight little communities which are bound together all the more closely because they have a sense of radical opposition to, and isolation from, the surrounding society. Insofar as the drive for belongingness is an important component of these movements, their ideological content can be quite flexible. If we view the underlying dimension as based in part on this motivation, there is common ground between the Belgian Separatists and the New Left groups.

The similarity goes beyond this. The Flemish separatists clearly are not seeking economic gains. Indeed, they seem prepared to sacrifice them for what they regard as cultural and humanitarian gains. In this respect also, they might be grouped with the New Left. After the need for belongingness, the next priorities (according to Maslow) are for self-esteem and self-actualization, and for fulfillment of one's intellectual and esthetic potential. In a somewhat chaotic way, most of these (postacquisitive) values seem to be reflected in the issues espoused by the New Left: the movement reflects a broad shift in emphasis from economic issues to life-style issues. ${ }^{31}$

"This ordering of priorities is, of course, not new in itself. Weber and Veblen, among others, called attention to the disdain for economic striving and an emphasis on distinctive life styles among economically securo strata throughout history. Veblen interprets the anti-acquisitive life style of past leisure classes as an attempt to protect their superior status by excluding individuals rising from lower economic levels. See Thorstein Veblen, The Theory of the Leisure Class (New York: Modern Library, 1934). It is highly dubious whether this interpretation applies to the contemporary post-bourgeois group as a whole. Its members appear universalistic in outlook and sometimes seem to imitate the life-style of lower strata. Conspicuous consumption seems to play a relatively small role in their behavior-unless we interpret going barefoot as a devious variation on conspicuous consumption. We would view needs for intellectual and esthetic self-realization as political motivations in themselves. Concern for pollution of the environnent and the despoiling of its natural beauty-issues which played a minor political role until quite recentlyhave suddenly become prominent, with the emergence into political relevance of the current youth cohorts. These concerns may be justified in terms of selfpreservation ("We are about to suffocate beneath an avalanche of garbage") but this argument may be somewhat hyperbolic: I suspect that behind this new wave of protest, there may be a heightened sensitivity to the esthetic defects of industrial society. It seems clear that other factors are also involved in the emergence of a New Left: situational factors unique to a given movement in a given society. I will not attempt to deal with them in this cross-national analysis.
We find a quite interesting relationship between value priorities and political party choice in our data. I have spoken of this phenomenon as reflecting a tendency toward reordering political party choices to bring them into harmony with underlying values. But this line of reasoning assumes a causal relationship, in which the value preference is an independent variable capable of influencing current party choice. To what extent is this assumption justified? It could be argued that the association between value priorities and party choice is spurious-that it results from the fact that given individuals have been raised in relatively conservative (or relatively Left-oriented) backgrounds, shaping them in a way which accounts for the presence of both the value preferences and the political party choice currently expressed.

It is difficult to provide a conclusive demonstration of what caused what, but we can subject the foregoing interpretation to an interesting test. Our respondents were asked a series of questions to ascertain what had been their parents' political party preference or (failing this) their general Left-Right tendance. Let us examine the relationship between value priorities and current party choice, controlling for the political background in which the respondent was raised (see Table 14). A comparison of the N's given for each group in Table 14 indicates that there is, indeed, some tendency for the children of Left-affiliated parents to show a relative preference for post-bourgeois values; the strength of this tendency varies considerably from country to country. But for present purposes, the crucial finding which emerges from Table 14 is that, even when we control for this source of variation, quite substantial differences persist between the political party preferences of acquisitive-oriented respondents and those of post-bourgeois respondents. In many cases, these differences become even larger than they were in Table 12. Table 14 shows the flow of voters from the party in which they were raised, to other parties-and the flow certainly does seem to be influenced by the value priorities of the individual. In the British sample, evidence of intergenerational defection from the two major parties is relatively weak, and we find two mildly anomalous cases (in which post-bourgeois respondents are a trifle less likely to support the Labour Party than are the acquisitive respondents). Even in the British sample, however, the net tendency is for Labour to be relatively strong and the Conservatives relatively weak among the post-bourgeois group, holding parental background constant. In our Dutch sample, among those raised 
by parents who supported one of the confessional parties, 78 per cent of the group showing acquisitive values remain faithful to those parties; by contrast, among those indicating postbourgeois values only 44 per cent have stayed with the church-linked parties-while an equal number have shifted their support to the parties of the Left (the Socialists; or Demokraten '66). Among Dutch respondents who were raised by supporters of the Socialist party, there seems to be greater continuity; fully 92 per cent of the post-bourgeois group say that they, too, would vote for the Left; among the acquisitive-oriented group, however, we find a rate of defection which is twice this high.

Quite sizeable differences appear in the Italian sample; most notably, among those raised in a Christian Democratic or Centrist background, only 4 per cent of the acquisitivetype respondents defect to the Left-as compared with 33 per cent among the post-bourgeois respondents. In the German sample, somewhat similarly, post-bourgeois respondents from Christian Democratic backgrounds show a relatively strong tendency to defect from this political affiliation: while 63 per cent of the "acquisitive" respondents remain in the Christian Democratic fold, only 46 per cent of the post-bourgeois respondents do so. The partisan shift seems to reflect a relative drawing away from the church-linked parties on the part of the post-bourgeois group: ${ }^{32}$ it continues the trend toward secularism traditionally associated with the Left. Indeed, the post-bourgeois group seems noticeably more sensitive to the supposedly outworn religious/secular cleavage than to the socioeconomic one: consistently, across our samples, the Christian Democratic parties show a heavy relative loss among this constituency, while the Liberal parties-which emphasize freedom of expression but often are more conservative on socioeconomic issues than the Christian Democrats-show a relative gain. The shift, indeed, seems more responsive to life-style values than to economic ones.

The most dramatic evidence of intergenerational change in political party loyalties is found in the French sample. Among the group raised within families which supported political

\footnotetext{
s2 The linkage between church and party is most explicit on the Continent, but the British Conservative Party is no exception to this pattern: affiliation with the Establisbed Church of England is strongly linked with preference for the Conservative Party. Even when wo control for social class, the Anglicans in our samplo are more likely to favor the Conservative Party than are members of minority faiths or nonreligious respondents, by a margin of nearly 20 percentage points. The more frequently one attends the Anglican Church, moveover, the more likely one is to support the Conservatives.
}

parties of the Right, those with acquisitive value priorities are very likely to continue in that tradition: 91 per cent support the Gaullist coalition. There seems to be an astoundingly high rate of defection among the post-bourgeois group, however; 70 per cent of them indicate that they would vote for one of the parties of the Left! Conversely, among those raised in a family which preferred the Left, there is little defection to the Gaullist coalition. Among the acquisitive value group, the rate of defection to the Gaullists is nearly five times as high: a substantial 29 per cent say that they would vote for one of the governing parties.

A number of the cells in Table 14 contain too few cases to be significant by themselves, ${ }^{33}$ but the overall pattern is clear: the presence of post-bourgeois values is linked consistently with a relative tendency to remain loyal to the Left, among those who were brought up in that tradition, and with a tendency to shift to the Left among those who were raised in other political climates. Jennings and Niemi have found evidence that recall data (such as ours) tends to exaggerate the degree of consistency between political party preferences of parent and child (perhaps as a result of the respondent's tendency to reduce cognitive dissonance). ${ }^{34}$ This finding implies that, if anything, our data probably understate the degree to which intergenerational party shift is taking place.

\section{Implications of Intergenerational Change}

Our conclusion, then, is that the transformation of value priorities which our data seem to indicate does imply a change in the social basis of political partisanship in most, if not all, of these countries. This change may already have been under way for some time. To illustrate: In the first elections of the Fifth Republic, the French electorate apparently voted along class lines to a very considerable extent. Lipset, for example, provides a table showing that working-class voters were 29 per cent more likely to support the parties of the Left than were members of the modern middle class, in $1958 . .^{35}$ Our

20 The reduced number of cases is due to the fact that here we are dealing only with those respondents:

1. Who have a political party preference-which they are willing to disclose; and

2. Whose parents had a political party preferencewhich was known by the respondent.

s4 See M. Kent Jennings and Richard G. Niemi, "The Transmission of Political Values from Parent to Child," The American Political Science Review, 62 (March, 1968), pp. 169-184.

${ }^{5}$ Calculated from Seymour M. Lipset, op. cit., Chapter V, Table IV. Our comparison focuses on the two more dynamic groups of industrial society-the workers, on one hand, and the modern middle class on the other hand. Although the principle is similar, our measure of class voting, therefore, is not identical 
Table 14. Intergenerational Party Shifts: Political Party Choice by Value Preferences, Controlling for Parents' Political Party

(Percentage choosing given party)

\begin{tabular}{|c|c|c|c|c|c|c|c|c|c|c|c|c|c|}
\hline \multicolumn{14}{|c|}{ Britain } \\
\hline \multirow{2}{*}{ Value Pref: } & \multicolumn{5}{|c|}{ Parents preferred Labour } & \multicolumn{4}{|c|}{ Parents preferred Liberals } & \multicolumn{4}{|c|}{ Parents preferred Conservatives } \\
\hline & \multicolumn{5}{|c|}{ Respondent would vote: } & Lab. & Lib. & Cons. & $\mathbf{N}$ & Lab. & Lib. & Cons. & $\mathbf{N}$ \\
\hline $\begin{array}{l}\text { Acquisitive } \\
\text { Post-Bourg. }\end{array}$ & & $2 \%$ & $\begin{array}{l}5 \\
7\end{array}$ & $\begin{array}{l}31 \\
21\end{array}$ & $\begin{array}{r}(185) \\
(47)\end{array}$ & $\begin{array}{l}23 \% \\
22\end{array}$ & $\begin{array}{l}17 \\
34\end{array}$ & $\begin{array}{l}61 \\
44\end{array}$ & $\begin{array}{l}(64) \\
(9)\end{array}$ & $\begin{array}{l}12 \% \\
10\end{array}$ & $\begin{array}{r}3 \\
13\end{array}$ & $\begin{array}{l}85 \\
77\end{array}$ & \multirow[t]{2}{*}{$\begin{array}{r}(171) \\
(31)\end{array}$} \\
\hline Difference: & + & & +2 & -10 & & -1 & +17 & -17 & & -2 & +10 & -8 & \\
\hline \multicolumn{14}{|c|}{ Germany } \\
\hline \multirow{2}{*}{ Value Pref: } & \multicolumn{4}{|c|}{ Parents preferred Socialists } & \multicolumn{4}{|c|}{ Parents preferred Liberals, FDP } & \multicolumn{5}{|c|}{ Parents preferred Christian Democrats } \\
\hline & $\begin{array}{l}\text { Resp } \\
\text { Soc. }\end{array}$ & $\begin{array}{r}\text { Fonde } \\
\text { FDF }\end{array}$ & $\begin{array}{r}\text { ent wo } \\
\text { P De }\end{array}$ & $\begin{array}{l}\text { Id vote: } \\
\text { r. } \\
\text { as. } \quad \mathrm{N}\end{array}$ & Soc. & FDP & $\begin{array}{l}\text { Chr. } \\
\text { Dems. }\end{array}$ & $\mathbf{N}$ & Soc & FD & & $\begin{array}{l}\text { Chr. } \\
\text { Dems. }\end{array}$ & $\mathbf{N}$ \\
\hline $\begin{array}{l}\text { Acquisitive } \\
\text { Post-Bourg. }\end{array}$ & $\begin{array}{l}87 \% \\
87\end{array}$ & $\begin{array}{l}4 \\
8\end{array}$ & & $\begin{array}{l}\text { (78 } \\
(36\end{array}$ & $\begin{array}{l}13 \% \\
40\end{array}$ & $\begin{array}{l}63 \\
60\end{array}$ & $\begin{array}{r}13 \\
0\end{array}$ & $\begin{array}{l}\text { (8) } \\
\text { (5) }\end{array}$ & $\begin{array}{l}35 \% \\
45\end{array}$ & $\begin{array}{l}2 \\
7\end{array}$ & & $\begin{array}{l}63 \\
46\end{array}$ & $\begin{array}{l}(115) \\
(41)\end{array}$ \\
\hline Difference: & & +4 & - & & & & & & +10 & +5 & & -17 & \\
\hline
\end{tabular}

France

\begin{tabular}{|c|c|c|c|c|c|c|c|c|c|c|c|c|c|c|c|}
\hline \multirow{3}{*}{ Value Pref: } & \multicolumn{5}{|c|}{ Parents preferred "Left," Comm., Soc } & \multicolumn{5}{|c|}{ Parents preferred Center, MRP } & \multicolumn{2}{|c|}{ Parents preferred } & "Right," & Indep., & \multirow[t]{2}{*}{ Gaullist } \\
\hline & & Respon & Ident wo & ould vo & & & & & & & & & & & \\
\hline & PSU & $\begin{array}{l}\text { Other } \\
\text { Left }\end{array}$ & & $\begin{array}{c}\text { UDR } \\
\text { RI }\end{array}$ & $\mathbf{N}$ & PSU & $\begin{array}{c}\text { Other } \\
\text { Left }\end{array}$ & Center & $\underset{\mathbf{R I}}{\mathbf{U D R},}$ & $\mathbf{N}$ & PSU & $\begin{array}{l}\text { Other } \\
\text { Left }\end{array}$ & Center & $\begin{array}{c}\text { UDR, } \\
\text { RI }\end{array}$ & $\mathbf{N}$ \\
\hline $\begin{array}{l}\text { Acquisitive } \\
\text { Post-Bourg. }\end{array}$ & $25 \%$ & $\begin{array}{l}60 \\
52\end{array}$ & $\begin{array}{l}5 \\
8\end{array}$ & $\begin{array}{r}29 \\
6\end{array}$ & $\begin{array}{l}(106) \\
(52)\end{array}$ & $\begin{array}{l}0 \% \\
35\end{array}$ & $\begin{array}{r}8 \\
26\end{array}$ & $\begin{array}{l}69 \\
39\end{array}$ & $\begin{array}{r}23 \\
0\end{array}$ & $\begin{array}{l}(13) \\
(23)\end{array}$ & 35 & $\begin{array}{r}4 \\
35\end{array}$ & $\begin{array}{l}5 \\
0\end{array}$ & $\begin{array}{l}91 \\
29\end{array}$ & $\begin{array}{l}(118) \\
(34)\end{array}$ \\
\hline Difference: & +19 & -8 & +3 & -23 & & +35 & +18 & -30 & -23 & & +35 & +31 & -5 & -62 & \\
\hline
\end{tabular}

Italy

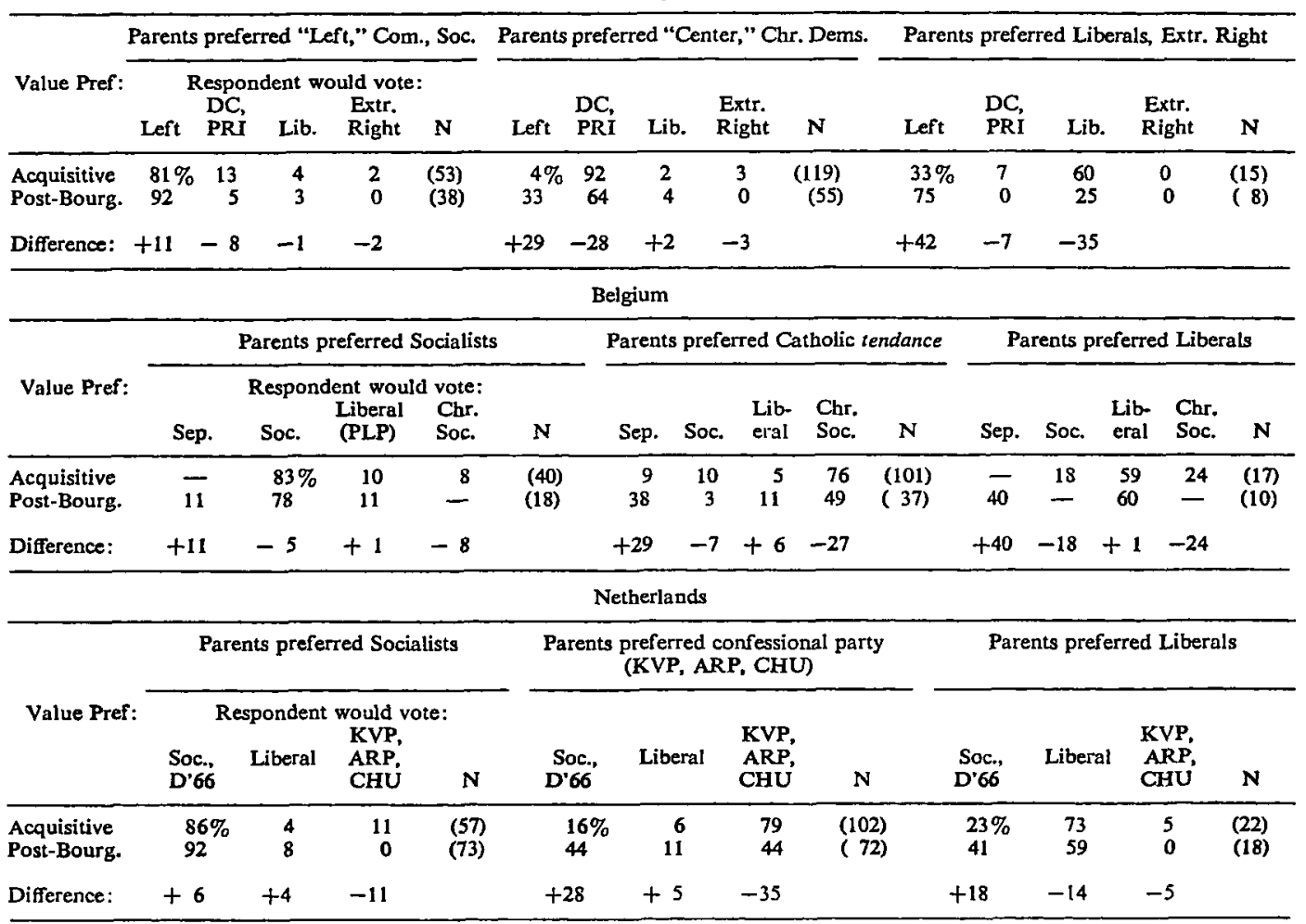


1968 survey indicated that the percentage spread between social classes was only about half this size in 1967 and that it dropped several points from 1967 to 1968 . Our 1970 data indicate little tendency for the French electorate to return to the 1967 level of class voting.

Paul Abramson, moreover, has recently reported evidence of a decline in the social class basis of political partisanship in France, Germany, and Italy-although not in Great Britain. ${ }^{36}$ Our own data suggest a pressure that should tend to reduce the incidence of class voting in Britain, but this pressure seems to be a good deal weaker there than in the Continental countries. We would expect the extent to which partisan repolarization actually takes place to be limited by the relative strength of existing political party identification in given countries: the comparatively high degree of repolarization apparent in France may have been facilitated by the relatively weak sense of political party identification which characterized the electorate of that country until very recently. Conversely, the relatively small amount of repolarization indicated in our British sample may reffect the presence of comparatively strong political party loyalties in Britain. A recent analysis of socialization data by Jack Dennis and Donald McCrone, for example, suggests that feelings of identification with a political party were less widespread and less intense in France than in any of five other Western democracies studied (although Dennis and McCrone find evidence of an increase over time in political party identifiers in France, a finding which our own data support). According to Dennis and McCrone, the publics of Great Britain and the U.S. apparently rank highest in extent and intensity of political party identifica-

with that used by Robert R. Alford in Party and Society (Chicago: Rand McNally, 1962). The traditional middle class, as a stagnant or declining element in the economy, has not shown a change comparable to that which apparently has taken place among the modern middle class; combining these two groups (as Alford does) dampens the effect we are describing.

*See Paul R. Abramson, "The Changing Role of Social Class in Western European Politics," Comparative Political Studies (July, 1971). Seymour M. Lipset and Stein Rokkan argue that "the party systems of the 1960's reflect, with but few significant exceptions, the cleavage structures of the 1920's"; see Lipset and Rokkan, Party Systems and Voter Alignments: CrossNational Perspectives (New York: The Free Press, 1967), p. 50. On the other hand, Lipset reports some data which seem to indicate a decline in class voting among the American electorate from 1936 to 1968: see Lipset, Revolution and Counter-Revolution: Change and Persistence in Social Structure (New York: Basic Books, 1968), Table 8-2, pp. 274-275. A change in degree, if not in type of cleavage, seems to be taking place. tion, with Germany and Italy ranking at intermediate levels. ${ }^{37}$

There may be still another reason why Britain continues to maintain the traditional class-vot-

${ }^{\text {s7 }}$ See Dennis and McCrone, "Preadult Development of Political Party Identification in Western Democracies," Comparative Political Studies, Vol. 3, No. 2 (July, 1970), pp. 243-263. This evidence confirms earlier findings: see Philip E. Converse and Georges Dupeux in Campbell et al., Elections and the Political Order; cf. Philip E. Converse, "Of Time and Partisan Stability," Comparative Political Studies, Vol. 2, No. 2 (July, 1969), pp. 139-171. In the latter two articles, Converse (and Dupeux) report that individuals who knew their father's party affiliation are more likely to identify with a party themselves than are those whose fathers did not transmit a cue concerning party identification. If citizens with a clear political party identification are relatively unlikely to shift their vote according to underlying values, Table 14 may give a conservative estimate of the impact of value priorities on party choice: the table deals exclusively with those who report a definite party choice themselves and received party preference cues from their parents. In addition, however, Converse finds (in "Of Time and Partisan Stability") that older cohorts tend to have relatively strong attachments to given political parties, as a function of the number of years they have been eligible to vote for the political party of their choice in free elections. This suggests the possibility that at least part of the relationship between value preference and party shift may be due to the greater liklihood of older respondents having "acquisitive" values and relatively strong party loyalties. This hypothesis might be tested by controlling for age, in addition to the other controls in Table 14. When we do so, the relationship between value preferences and party shift does not seem to disappear, but the highly skewed relationship between age and values reduces the number of cases in some of the cells to the vanishing point. We can apply another sort of test, however, based on cross-national comparisons. Our 1968 data from Britain, France and Germany contain information about the strength of party identification. The pattern varies a good deal from country to country. In the British sample (where the present party system has been established for nearly half a century) intense partisan identification falls off regularly and sharply, as we move from oldest to youngest age group. The oldest British group contains four times as many strong partisan identifiers as does the youngest group. Intense partisanship falls off regularly but less steeply in the German sample (strong identifiers occurring twice as frequently among the oldest group as among the youngest group). So far, this is entirely consistent with the pattern reported by Converse. The French data, however, fit Converse's model only if we regard the present French party system as newly established: partisanship decreases only very slightly in the French sample, as we move from old to young. French teenagers are almost as likely to declare themselves strong partisans as are the 60-year-olds! While at other age levels the French are least likely of the three nationalities to express a strong sense of party identification, among this youngest group they show the highest proportion. The relationship between intergenerational party shift and underlying value priorities noted in our French sample cannot readily be attributed to the older cohorts' relatively strong attachment to existing political parties-yet value-linked intergenerational party shift seems to occur to a greater extent in France than in any of the other national samples. 
ing pattern of industrial society: the British Labour Party has never been a party of the Left in the same sense as the Marxist parties on the Continent. From the start, it has been a party of moderate reform, rather than one of revolution. Thus, there is less contrast between Labour and Conservative in Britain than between Left and Right on the Continent; an embourgeoisified worker can continue to feel comfortable in voting for the Labour Party ${ }^{38}$ while, conversely, a post-bourgeois Englishman has less incentive to switch from Conservative to Labour.

For the time being (as Table 2 indicates), the acquisitive group is much larger than the post-bourgeois group in all of these countries: in case anyone doubted it, the squares outnumber the swingers. In practical terms, this suggests that the potential reservoir of voters who might shift to the Right is larger than the potential base for the New Left. But if our cross-temporal interpretation is correct, this situation is in a process of rapid change. Assuming intracohort stability in value priorities, ${ }^{39}$ a projection of changes due to recruitment and mortality based on Table 5 suggests that the two pure groups might reach numerical parity-on the Continent-within the next 20 years. Given the fact that the post-bourgeois types tend to be highly educated, they are likely to be better organized and politically more active than the acquisitiveoriented group. In terms of political effectiveness, the two groups might reach parity within, say, the next 15 years (these projections apply to the European Community countries; Britain appears to lag behind them by about ten years).

The size of the partisan redistribution in France in 1968 may give an idea of the extent

* Even relatively affluent English workers are likely to remain staunch supporters of the Labour Party, according to John H. Goldthorpe, David Lockwood, Frank Beckhofer and Jennifer Platt: see The Affuent Worker: Political Attitudes and Behavior (Cambridge: Cambridge University Press. 1968). Richard F. Hamilton argues that the same was true of French workers during the Fourth Republic; he may be correct in regard to that period, but our data indicate that the pattern has changed significantly during the Fifth Republic. See Hamilton, Affiuence and the French Worker in the Fourth Republic (Princeton: Princeton University Press, 1967).

"At first glance, the assumption of intracohort stability may seem unrealistic: adult change does take place. But, for reasons indicated above, it would probably be rash to assume that the adult cohorts will necessarily become more acquisitive as they age. In view of the uncertainty of the direction of possible shifts within adult cohorts, the assumption of intracohort stability may provide at least a useful first approximation. to which-under crisis conditions-a similar repolarization might take place in the other countries at the present time. But this process can, of course, be influenced by situational factors, such as political leadership in the given countries. The levels of support for the SPD indicated in our 1970 survey suggest that Willy Brandt, for example, has succeeded in doing what the French Left notably failed to do in 1968 - to attract the post-bourgeois group without alienating the acquisitive types.

In Western Europe as a whole, the prospective social base for movements of radical social change appears likely to increase sharply during the next two decades. But in order to be effective, movements seeking radical change must shape their tactics with an awareness of current realities. In view of the wide preponderance which the acquisitives seem to hold over post-bourgeois respondents in Western electorates, a Weatherman-type strategy (for example) not only seems likely to be counterproductive in the short run; to the extent that it had any real impact on the economy, it apparently would tend to be self-defeating in the long run as well.

The new Left-Right continuum resembles the old in that it pits forces of change against those of the status quo-but the values motivating change relate to life styles rather than acquisition, and the social bases supporting change show a corresponding shift. For the time being, the potential social base for the New Left may be a distinct minority. The older value groups are still split, however, and a New Left could be politically effective through alliances with the Old Left which emphasize economic issues-even, to some extent, at the price of playing down some of the expressive issues which are most appealing to the New Left constituency. Conversely, when partisans of the New Left appear to threaten the basic social order (as in France, in May, 1968), they emphasize a cleavage which isolates them from both factions of the acquisitive-oriented population: they threaten to upset an apple cart which has for twenty years provided an unprecedented supply of apples. The post-bourgeois group may contend that the apples are sour. They may be right. But the difference in opinion springs from an ingrained difference in tastes.

The present essay has, no doubt, only scratched the surface in the analysis of intergenerational value changes within advanced industrial societies. Further efforts are needed in developing more accurate and more exhaustive measurements of such changes, and in applying 
these measurements to a longitudinal data base. In this early exploration, we find a fair amount of evidence that our indicators of value priorities tap basic aspects of an individual's belief system: a number of other attitudinal items show relatively great constraint in relation to these value indicators, and the response pattern seems integrated into the social structure in a way which suggests that these values are earlyestablished and relatively stable. Moreover, cross-national differences in value choices have a fit with the economic history of these countries, over the past two generations, which further seems to support this interpretation. It seems at least plausible to conclude that intergenerational change is taking place in the value priorities of West European populations-and that this change may have a significant longterm impact on their political behavior. ${ }^{40}$ tw These findings seem to contradict some key projections in the literature which focuses on analysis of the future. Herman Kabn and Anthony Wiener, for example, contend that:

There is a basic, long-term multifold trend toward:

1. Increasingly sensate (empirical, this-worldly, secular, humanistic, pragmatic, utilitarian, contractual, epicurean or hedonistic) cultures.

2. Bourgeois, bureaucratic, "meritocratic," democratic (and nationalistic) elites. ...

My reading of the data implies that, while these trends may bave prevailed until recently, certain aspects may be undergoing a reversal in post-industrial societies. Specifically, I doubt that the elites of these societies will become increasingly bourgeois, meritocratic or nationalistic; or that these cultures are likely to become increasingly pragmatic or utilitarian. Kahn and Wiener make a number of additional projections which do strike me as likely to bold true; see The Year 2000: A Framework for Speculation on the Next ThirtyThree Years (New York: Macmillan, 1967), p. 7. 